\title{
A comparative study on ASCE 7-16, TBEC-2018 and TEC- 2007 for reinforced concrete buildings
}

\author{
Ceyhun Aksoylu (Main author)
}

Department of Civil Engineering, Faculty of Engineering and Natural Sciences, Konya Technical University Konya 42075 (Turkey)

caksoylu@ktun.edu.tr

\section{Ahmed Mobark}

Department of Civil Engineering, Faculty of Engineering and Natural Sciences, Konya Technical University Konya 42075 (Turkey)

ahmeed696@yandex.com

\section{Musa Hakan Arslan (Corresponding author)}

Department of Civil Engineering, Faculty of Engineering and Natural Sciences, Konya Technical University Konya 42075 (Turkey)

mharslan@ktun.edu.tr

\section{İbrahim Hakkı Erkan}

Department of Civil Engineering, Faculty of Engineering and Natural Sciences, Konya Technical University Konya 42075 (Turkey)

iherkan@ktun.edu.tr

\author{
Manuscript Code: 14052 \\ Date of Acceptance/Reception: 20.06.2020/19.10.2019 \\ DOI: 10.7764/RDLC.19.2.282
}

\begin{abstract}
Doctrines of earthquakes and also the latest approaches of earthquake resistant building design in standards need to be revised periodically. While the revisions and updates in the American standards occur over periods of three or five years including limited subjects, in Turkey the same revisions are done once over long periods including the whole subjects of the standards. As examples the standards of 1975, 1998, 2007 and finally 2018 could be given. Especially, in 2018 standard (TBEC-2018) many changes were made over concepts and criteria. The procedure of calculating the earthquake loads in 2018 standards is similar to the one in the American standards of (ASCE-7-16), however for the element design the changes are shown as developments over the one of 2007 earthquake standard (TEC-2007). The changes made by 2018 standard for calculations of earthquake loads and their effects on civil engineering are very important factors of new building design. The earthquake load affecting a building which is the first factor of earthquake resistant building design shows important differences according to the condition changes in the standard. Based on this motivation in this study reinforced concrete frame type buildings of different elevations were researched by using ETABS (structural software for building analysis and design) according to linear equivalent seismic load method. According to the analysis results of the chosen buildings, a comparison forthe base shear force, top displacement and relative story displacement between TEC-2007, TBEC-2018 and ASCE 7-16 standards was carried out. From the analysis results, it is found that for most of the soil classes while the maximum base shear forces in 3 and 5- story buildings are achievedat TEC-2007, the maximum base shear forces in 7 and 9- story buildings are achieved at TBEC-2018. Also, it is predicted that the higher increment in the design forces of buildings with higher elevations is obtained at TBEC-2018 for strong soils, and at TEC-2007 for weak soils. By considering cracked sections at TBEC-2018 the calculations displacement and period was affected as periods in TBEC-2018 were increased by almost 34\% respected to TEC-2007. The same increment ratio was determined for ASCE $7-16$ as $45 \%$. Also, as a response for the increments in period, the spectral acceleration determined from the elastic spectrum diagram was decreased. At the end of the study, nonlinear performance analysis was also performed and performance points were determined according to the demand spectra of the seismic codes. ASCE's demand displacement values are in any case lower than Turkish codes. TBEC-2018 reveals less displacement demands in high-rise buildings than TEC-2007. The closest results for the three regulations occurred on the softest grounds.According to the results obtained from the static pushover analysis, a ductile behavior occurred in all of the structural systems and plastic hinge mechanism started from the beams firstly.
\end{abstract}

Keywords: ASCE 7-16, TBEC-2018, TEC-2007, earthquake standard, seismic force.

Nowadays by using technology building design became more practical compared to the past. Benefitting from the developed softwares of building analysis, made it possible to save time as obtaining fast and right results only takes a few minutes. By considering the effects of earthquake in the countries lie on the earthquake zone especially in Turkey (Arslan, 2010; Arslan \& Korkmaz, 2007; Erdik, 2004; Sezen \& Andrew, 2006; Sezen, Whittaker, Elwood, \& Mosalam, 
2003), earthquake resistant building design becomes more important. For transferring earthquake effects more preciously to the building Turkish Earthquake standard-2007 (TEC, 2007) was updated after eleven years under the name of Turkey Buildings Earthquake Standard-2018 (TBEC, 2018). In 1975-code, ductile design expression was used for the first time. In 1998-code, capacity design was developed. In 2007- earthquake standard, nonlinear calculation method and performance analysis for existing reinforced concrete buildings were added partially. Most of calculation and design rules used in 2007 standard were established depending on 1998-standard. Despite the differences found between these two standards, it is certain that 2007-standard basically depends on 1998-standard.

The seismic zones in 2007 which are the most significant parameter of earthquake calculation that fall down in value from $1^{\text {st }}$ degree till $4^{\text {th }}$ degree were invalidated by 2018-standard and the new seismic hazard map. In 2018-standard seismic design category (SDC or in Turkish code DTS) is determined according to the values of building importance and potential seismic acceleration of soil. DTS is classified from 1 to 4 with a total of 8 categories. This way 8 different DTS categories were developed by the new standard. Combining seismic design category and Occupancy category produced an effective parameter that is applied in the new calculations of seismic acceleration. By applying a set of categories on the building elevation some changes related to them took place in the calculations.

Turkey seismic hazard maps released by Disaster and Emergency Management Authority (in Turkish AFAD) (AFAD, 2009) researches was used for the first time in parallel to 2018-standard. Therefore, data based on geologic researches could be considered in building analyses with 2018 standard from now and later on like the application in ASCE 7-16 (ASCE716, 2017). A lot of the changes applied in 2018 standard are similar to the scope of ASCE 7-16 standard. Especially soil category was given in detail as a new separate section of the standard. Soil-structure interaction on the seismic response of the frame structure is crucial on the seismic behavior (Guerdouh \& Khalfallah, 2019). While in 2007 standard site class was defined like 1998 standard as for soil zones in which Z1 is the strong and Z4 is the weakest zone, in 2018 standard both site class and soil profile were combined and shown under the same table with an arrangement from $A$ to F exactly like ASCE 7-16 standard. Therefore, site classes in TEC-2007 could be expressed into pairs respecting to TBEC-2018 and ASCE 7-16 standards as followed; Z1 (ZA, ZB, A, B), Z2 (ZC, C), Z3 (ZD, D) and Z4 (ZE, E). For F site class in accordance with 2018 standard a site response analysis is required. Despite the similarity in site class between TBEC2018 and ASCE 7-16 standards by which design acceleration coefficient is determined, there are still some differences in their details.

The academic researches about TBEC-2018 is so recent (Aksoylu \& Arslan, 2019). Yet some researches are already exist in the literature about its draft form of 2016. In the recent researches in which 2018 and 2007 standards were compared foundation design forces, the researchers compared building displacements, building periods and spectral acceleration curves (Aksoylu \& Arslan, 2019). According to the researches done by (Erdem \& Bikçe, 2017) on 2018 standard it was found that applying joint for infill walls duplicates the permissible drift. (Tunç \& Tanfener, 2016) applied 2018 standard in the period calculation of a 10-story office building and found an increase by $20-25 \%$ with respect to 2007 standard. The main reason for this increase depends on the calculations of the effective rigidity as mentioned in (Öztürk, Demir, Dok, \& Güç, 2017). In 2018 standard it is necessary for the effect of cracks in sections to be considered. According to the nonlinear time history analyses run for 2007 and 2018 standards by (Demir \& Kayhan, 2017) it was concluded that different results would be obtained. In the studies of Şahin, Aksoylu, \& Arslan (2018) they found that there are significant differences in periods between 2007 and 2018 standards. Also it was concluded that for the same location seismic acceleration values changes with respect to the soil category. These results were verified by (Keskin \& Bozdoğan, 2018; Kocer, Nakipoglu, Ozturk, Al-Hagri, \& Arslan, 2018; Ozturk, 2018).

In literature there are also many researches that compare the calculation procedures for different seismic standards. For example, in (Dogangun \& Livaoglu, 2006) design spectrum of TEC-2007 standard was compared to design spectrums of UBC (Uniform Building Code), EC8 (Eurocode8) and IBC (International Building Code). Comparisons were made for different site classes considering periods, base shear forces, lateral displacements and relative story drift. Also (Wziatek, 2015) made a comparison between ASCE 7-10(ASCE7-10, 2010), ACI 318(ACI318-08, 1989) and IBC-2012(IBC, 2012) standards by calculating the base shear forces and relative story drifts for beam, column and wall elements then determining reinforcement areas for those designs. In the researches done by (Abdel Raheem, Ahmed, \& Ahmed, 2018) L type building was investigated according to UBC-97 (UBC, 1997), EC8 (Eurocode8, 2004), NBCC-95 (NBCC-95, 1995), TEC-2007 and ASCE 7-10 standards considering relative story drift, base shear force and torsional irregularities. From this study it was concluded that slab discontinuity in L type structure loaded with seismic loads changes the performance of the structure highly at lateral drift and the relative story drift. Designers recommended considering these factors during designing step. Moreover, many researchers have conducted studies to investigate the seismic performance of existing RC buildings (Gunes et al., 2019; Mosleh et al., 2016; Cherifi et al., 2015; Sobaih \& Nazif, 2012; Sezer et al., 2016). 
In this study 2007 and 2018 Turkish earthquake standards were compared with ASCE 7-16 earthquake standard considering parameters such as base shear force, top displacement, period of structure and relative story displacement. Analyses were done using ETABS structural analysis program. For the comparison a 3,5,7 and 9-story reinforced concrete structures of frame type and without irregularity were chosen as their elevation categories are suitable for the equivalent seismic load method to be applied. Analyses were done in groups so that all site classes could be considered. At the end of the study, nonlinear performance analysis was also performed and performance points were determined according to the demand spectra of the seismic codes.

\section{Comparing standards with each other}

By validating TBEC-2018 in 2019 fundamental changes took place in design calculations with respect to TEC-2007. TBEC2018 became similar to ASCE 7-16 in general. The most significant change was in the acceleration values used in seismic load calculations. The seismic zonation map used in Turkey since 1996 was replaced by seismic hazard map in 2019. By applying this map determining the seismic acceleration would depend on the values of $\mathrm{S}_{s}$ and $\mathrm{S}_{1}$ found from the map for each single geographical point. These two values represent the spectral acceleration coefficients of the map corresponding to 0.2 short period and 1 second long period zones respectively. Later on, the designer use the design spectral acceleration coefficients obtained by multiplying with $\left(F_{s}\right.$ and $\left.F_{1}\right)$ coefficients that show the soil characteristics where the structure would be constructed. As a result of this; instead of the single spectral acceleration coefficient determined according to the seismic zone in 2007 standard, two different coefficients according to short and long period zones in 2018 standard could be determined. Actually these new concepts in TBEC-2019 are the calculations applied over long years in ASCE 7 standard since ASCE 7-02 till ASCE 7-16 (Arteta \& Moehle 2018; Moehle, 2014; Arroyo, Barros, \& Ramos, 2019; Visnjic, Panagiotou, \& Moehle, 2015). In addition, the new standard applied many changes similar to ASCE standard. Some of those changed or recently defined concepts such as site class, occupancy category, seismic design category, building height category, system over strength and effective rigidity are considered to be shared by the two standards. DTS is determined according to the acceleration values and building importance (I) obtained. In 2018 standard there are different 4 seismic design categories like 2007 standards. For important building situations (such as; hospital, school etc.) the letter "a" is attached to the seismic design category. Another change made in 2018 standard is that buildings of the second importance (1.4) in 2007 standard like school, museum, army barracks and jails were raised up to the first importance (1.5).

In 2018 earthquake standard building height category (BHC or in Turkish code BYS) was defined independently of 2007 earthquake standard a similar way to ASCE 7-16. Building height category varies between BYS1 and BYS8 according to total building height and DTS. Buildings of BYS1 are explained in detail in a different section of the standard under the title of high buildings.

Another remarkable change at TBEC-2018 is that beside the seismic structure behavior factor (R) existing in TEC-2007, also system over strength (D) is applied. Strength-based design approach (DFT) came to the fore by the validation of TBEC-2018. System over strength (D) is determined depending on building characteristics like R factor. Its aim is to keep the structure elements of brittle characteristic within the elastic limits at each condition by increasing the internal forces using D coefficient. D coefficient was defined at TBEC-2018 for each element between 1.5 and 3.5 according to the structure type. For building designs depending on strength-based design approach it is necessary to consider the effective rigidity of the elements. For designs under the same situation, it is required to consider the bending stiffness (EI) of column, beam and wall respectively as $70 \%, 35 \%$ and $50 \%$ of their initial values.

Also applying cracked rigidities of sections affects the period calculations for buildings. Because of the various factors affecting the building it is so difficult to calculate its natural seismic period accurately. This why approach methods for period calculation were given in the literature. The most accepted method among them is the one suggested by Rayleigh which is the period equation accepted by almost all of the seismic standards. The period calculation in 2007 seismic standard is done according to the moment of inertia of uncracked section. On the other hand, in 2018 seismic standard this calculation is done according to the moment of inertia of cracked section like the calculations applied by ASCE 716. According to ASCE 7-16 cracked section rigidities of column and beam must be respectively $70 \%$ and $35 \%$ of the initial values. Applying this method on buildings affected by lateral loads results in much displacement and larger natural seismic period, however ASCE 7-16 unlike the other two standards suggested Rayleigh equation for nonstructural elements too. 


\section{The procedure of calculating equivalent seismic load in the standards}

The period value considered at building designs of equivalent seismic load method (ESLM: static linear-Equivalent Static Lateral Force Method) is the dominant period value obtained from the first Mod. For calculating the period value, the equation suggested by Rayleigh \& Ritz in 1877 and 1909 respectively (Leissa, 2005) and known in literature only by Rayleigh method is applied most of the time. According to equivalent seismic load method, it is very important to calculate the period value correctly. This is because according to the standards the elastic acceleration value affecting the building during an earthquake is determined from a spectrum curve depending on the period value. In this section the procedure of calculating equivalent seismic will be summarized shortly considering 3 standards.

\section{TEC-2007 Approach}

For buildings in which ESLM would be applied 2007 seismic standard restricted the irregularity and stories. While the height for buildings with soft story irregularity in very active seismic zone is not allowed to exceed 25 meters, this height was raised up to $\mathbf{4 0}$ meters in seismic zones with low activity. Also it is possible to raise the height limitation in active seismic zone up to $\mathbf{4 0}$ meters if there is no torsional risk. In this case and by considering an average story height of 3.5 meters, this standard could be applied for at most buildings with 11 stories. The total building weight considered in the analysis of equivalent seismic load includes both dead loads $\left(g_{i}\right)$ and live loads $\left(q_{i}\right)$. Live loads are multiplied with coefficients varying between $0.3,0.6$ and 0.8 according to occupancy category of the building. Spectral acceleration coefficient $A(T)$ considered in determining the seismic load affecting the building, is calculated by the function given in (Table 1). The elastic spectral acceleration $\mathrm{S}_{a e}(\mathrm{~T})$ which is the ordinate value for elastic acceleration spectrum defined by the $5 \%$ damping ratio is equal to the multiplication of spectral acceleration coefficient and gravity acceleration $g$ $\left(9.81 \mathrm{~m} / \mathrm{s}^{2}\right)$. The effective ground acceleration coefficient $A_{0}$ for each seismic zone varies between 0.4 and 0.1 . In order to consider the nonlinear nonelastic behavior of the building during earthquake elastic seismic loads are divided by seismic load reduction factor $\left(R_{a}\right)$ that defined in (Table 1 ) into two conditions with respect to the period value. Seismic load reduction factor $R_{a}(T)$ depends on structural behavior factor $(R)$, natural seismic period $\left(T_{n}\right)$ in first mod of the building and site class. $A$ table was given in the standard for corner periods ( $T_{A}$ and $T_{B}$ ) that vary with respect to the local site soil (Z1, Z2, Z3 and Z4). While Z1 represents rock soils, Z4 represents soils with alluvial characteristic. While $T_{A}$ and $\mathrm{T}_{\mathrm{B}}$ for $\mathrm{Z1}$ are defined respectively as $0.10 \mathrm{~s}$ and $0.30 \mathrm{~s}$, For $Z 4$ the same values are defined as $0.20 \mathrm{~s}$ and $0.90 \mathrm{~second}$. According to the equivalent seismic load method, the dominant natural seismic period is calculated by the equation suggested by Rayleigh as shown in Table 1 . Here, $m_{i}$ : is the mass of the $i^{\text {th }}$ story. $F_{f i}$ is the fictive load acting on the $i^{\text {th }}$ story. $d_{\mathrm{fi}}$ : is the displacement calculated for the same point at the seismic direction during the acting of fictive loads. Spectrum coefficient $\mathrm{S}(\mathrm{T})$ is calculated as shown in Table 1 according to site class and natural seismic period (T). According to TEC-2007 for achieving satisfied rigidities at buildings, the effective relative story displacement must be restricted to a certain limit. Therefore, for a direction of earthquake the maximum effective relative story displacement $\left(\delta_{i}\right)$ of the columns and walls at each story must achieve the criteria given Table 1 . Here while the effective story displacement value is represented by $\delta_{i}$ story height is represented by $h_{i}$. The effective story displacement value $\left(\delta_{i}\right)$ is calculated by multiplying the values of structural behavior factor $(R)$ with the reduced relative story displacement $\left(\Delta_{i}\right)$. For determining the allowed maximum value of the relative story displacement at each story the equation given in Table 1 is applied.

\section{TBEC-2018 Approach}

The average geometry map for seismic effects with horizontal two orthogonal directions are represented in TBEC 2018 by spectral acceleration coefficients. According to the condition of the soil that considered for a certain seismic ground motion level, these coefficients are obtained by dividing spectral accelerations given in seismic hazard maps of 5\% damping ratio by gravity acceleration $\left(g=9.81 \mathrm{~m} / \mathrm{s}^{2}\right)$ as dimensionless values. Map spectral acceleration coefficients $\mathrm{S}_{\mathrm{s}}$ and $S_{1}$ of different four seismic ground motion level were defined on seismic hazard maps according to short period and 1 second period respectively. The coefficients of spectral acceleration maps are transformed into the coefficients of design spectral acceleration $S_{D S}$ and $S_{D 1}$ as shown in Table 1. $F_{S}$ and $F_{1}$ in these equations are the coefficients of the local soil. By using the coefficients of design spectral acceleration obtained the horizontal and vertical elastic design spectrums are calculated. On the other hand, the horizontal elastic design spectral acceleration values Sae $(T)$ which are the ordinates of the horizontal elastic design spectrum for any seismic ground motion level, are calculated in term of gravity acceleration (g) as shown in Table 1 . In these equations, SDS and SD1 represent design spectral acceleration coefficients. And T represents the natural period of the building. $T_{A}$ and $T_{B}$ represent the corner periods of the horizontal design spectrums as shown in Table 1. Building occupancy categories used in determining the seismic design category (SDC) is defined in the same time with building importance factor that varies between $1 \leq 1 \leq 1.5$ according to the occupancy of the building. In TBEC-2018 while building importance factor (I) is chosen as 1 in residential buildings 
and 1.5 in hospitals, it is determined that $R=8$ and $D=3$ in condition of Building height category $\geq 3$ and only for buildings in which seismic effects are totally carried by reinforced concrete frames of high ductility. In order to consider the nonlinear nonelastic behavior of the building during earthquake elastic seismic loads are divided by $R_{a}$ that defined in (Table 1), however unlike TEC-2007 during the calculations of $R_{a}(T)$ also system over strength (D) is considered. In addition, the comparisons are made for 1 . Mod period value against $T_{B}$ unlike TEC-2007 in which comparisons are made against $\mathrm{T}_{\mathrm{A}}$. The total ESL acting on the whole building at the considered seismic direction under equivalent seismic loading condition, is calculated as shown in Table 1. Here, $\mathrm{m}_{\mathrm{t}}$ is the total mass of the building. $\mathrm{S}_{\mathrm{aR}}(\mathrm{T})$ is obtained by dividing the horizontal elastic spectral acceleration $\left(\mathrm{S}_{\mathrm{ae}}(\mathrm{T})\right.$ ) by seismic load reduction coefficient $\left(R_{a}\right)$.

Table 1. The Equations of the standards Source: Self Elaboration.

\begin{tabular}{|c|c|c|c|}
\hline & TEC-2007 & TBEC-2018 & ASCE 7-16 \\
\hline $\begin{array}{l}\text { Step } \\
\text { 1:Determining the } \\
\text { spectral curve }\end{array}$ & $A(T)=A_{0} * I * S(T)$ & $\begin{aligned} S_{D S} & =S_{S} * F_{S} S_{D 1}=S_{1} * F_{1} \\
T_{A} & =0.2 * \frac{S_{D 1}}{S_{D S}} T_{B}=\frac{S_{D 1}}{S_{D S}}\end{aligned}$ & $\begin{array}{l}S_{M S}=F_{a} * S_{S} S_{M 1}=F_{v} * S_{1} \\
S_{D S}=\frac{2}{3} * S_{M S} S_{D 1}=\frac{2}{3} * S_{M 1}\end{array}$ \\
\hline $\begin{array}{l}\text { Step } \\
\text { 2:Determining the } \\
\text { period of the } \\
\text { building }\end{array}$ & $T_{1}=2 \pi * \sqrt{\sum_{i=1}^{N} \frac{m_{i} * d_{f i}^{2}}{F_{f i} * d_{f i}}}$ & $T_{p}=2 \pi * \sqrt{\sum_{i=1}^{N} \frac{m_{i} * d_{f i}^{2}}{F_{f i} * d_{f i}}}$ & $\begin{array}{c}T_{a}=C_{t} * H_{N}^{x} \\
\left(T_{a}\right)_{\max } \leq C_{u} * T_{a}\end{array}$ \\
\hline $\begin{array}{l}\text { Step 3:The elastic } \\
\text { acceleration is } \\
\text { calculated } \\
\text { according to the } \\
\text { period and elastic } \\
\text { seismic force is } \\
\text { calculated }\end{array}$ & 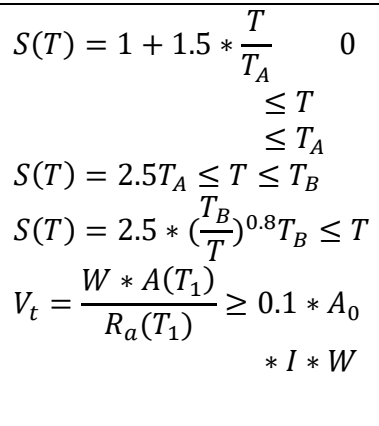 & $\begin{array}{c}S_{a e}(T)=\left(0.4+0.6 * \frac{T}{T_{A}}\right) * S_{D S} 0 \leq T \\
\leq T_{A} \\
S_{a e}(T)=S_{D S} T_{A} \leq T \leq T_{B} \\
S_{a e}(T)=\frac{S_{D 1}}{T} T_{B} \leq T \leq T_{L} \\
S_{a e}(T)=\frac{S_{D 1} * T_{L}}{T^{2}} T_{L} \leq T \\
V_{t E}^{X}=m_{t} * S_{a R}\left(T_{p}^{X}\right) \\
\geq 0.04 * m_{t} * I * S_{D S} \\
* g\end{array}$ & $\begin{array}{c}F_{x}=C_{v x} * V \\
V_{x}=\sum_{i=x}^{n} F_{i} \\
V=C_{S} * W \\
C_{v x}=\frac{w_{x} * h_{k}^{x}}{\sum_{i=1}^{n} w_{i} * h_{i}^{k}}\end{array}$ \\
\hline $\begin{array}{l}\text { Step 4: The elastic } \\
\text { seismic force is } \\
\text { reduced with } \\
\text { respect to the } \\
\text { structural behavior } \\
\text { factor. }\end{array}$ & $\begin{aligned} R_{a}(T)=1.5+(R & -1.5) \\
& * \frac{T}{T_{A}} 0 \\
& \leq T \\
& \leq T_{A} \\
R_{a}(T)=R \quad T_{A} & \leq T\end{aligned}$ & $\begin{array}{c}R_{a}(T)=\frac{R}{I} T>T_{B} \\
R_{a}(T)=D+\left(\frac{R}{I}-D\right) * \frac{T}{T_{B}} T \leq T_{B}\end{array}$ & $\begin{array}{c}C_{S}=\frac{S_{D S}}{\left(\frac{R}{I_{e}}\right)} C_{S} \\
=\frac{S_{D 1}}{T *\left(\frac{R}{I_{e}}\right)} \quad T \leq T_{L} \\
C_{S}=\frac{S_{D 1} * T_{L}}{T^{2} *\left(\frac{R}{I_{e}}\right)} T>T_{L} \\
C_{S}=0.044 * S_{D S} * I_{e} \geq 0.01 \\
C_{S}=\frac{0.5 * S_{1}}{\left(\frac{R}{I_{e}}\right)} S_{1} \geq 0.6 \mathrm{~g}\end{array}$ \\
\hline $\begin{array}{l}\text { Step 5:Elastic } \\
\text { displacement } \\
\text { limits are } \\
\text { controlled }\end{array}$ & $\begin{array}{l}\frac{\left(\delta_{i}\right)_{\max }}{h_{i}} \leq 0.02 \\
\Delta_{i}=d_{i}-d_{i-1} \text { ve } \delta_{i}=R * \\
\Delta_{i} \\
\left(\Delta_{i}\right)_{\max } \leq 0.02 * \frac{h_{i}}{R}\end{array}$ & $\begin{array}{c}\lambda * \frac{\delta_{i, \max }^{X}}{h_{i}} \leq 0.008 * \mathrm{\kappa} \\
\lambda * \frac{\delta_{i, \max }^{X}}{h_{i}} \leq 0.016 * \mathrm{\kappa} \\
\delta_{i, \max }^{X}=\frac{R}{I} * \Delta_{i}^{X} \\
\Delta_{i}^{X} \leq \frac{0.008 * h_{i} * I}{R * \lambda} \\
\Delta_{i}^{X} \leq \frac{0.016 * h_{i} * I}{R * \lambda}\end{array}$ & $\begin{array}{c}\delta_{x}=\frac{C_{d} * \delta_{x e}}{I_{e}} \delta_{x e}=\Delta_{i} \\
\frac{C_{d} * \Delta_{i}}{I_{e}} \leq 0.020 * h_{s x} \\
\frac{C_{d} * \Delta_{i}}{I_{e} * h_{s x}} \leq 0.020\end{array}$ \\
\hline
\end{tabular}

While in TEC-2007 the cracks that occur in sections were not considered in the rigidity calculations of element designs, in TBEC-2018 according to the element type various crack and rigidity loss ratios were suggested. According to TBEC2018 designs the loss of inertia in beams, columns and reinforced concrete (RC) wall must be $65 \%, 30 \%$ and $50 \%$ respectively. In this case, a change in the calculated period is noticed which in role affects the values of design forces and displacements. For achieving the seismic security and satisfied rigidity in building designs the maximum relative story displacement values of columns and RC walls at each story were applied almost for all seismic standards. Yet, in some standards for determining the maximum relative story displacement not only damages with structural elements but also damages with non-structural elements (such as filled walls) were considered during earthquake (Sindel, Akbaş, \& Tezcan., 1996). According to Turkey standards between 1949 and 2007 non-structural elements were not considered during restricting the relative story displacement. Brick walls were applied only by considering their weights. Yet TBEC- 
2018 has developed different two relative story displacement limits according to the connection and the disconnection between filled walls and reinforced concrete fames. In TEC-2007 this value was related only to $h_{i}$ and R. Yet in TBEC2018 in addition to these factors also I value and the case of connection/disconnection between filled wall and reinforced concrete frames were considered through calculations. For considering the connection and disconnection between infilled wall and reinforced concrete frames in determining the effective relative story displacement according to TBEC-2018 equations are given in Table 1. In these equations, story height is "hi". The maximum value of the effective relative story displacement of $\mathrm{i}^{\text {th }}$ story of a building in $\mathrm{x}$ direction is " $\mathrm{\delta}_{\mathrm{i}, \max }$ ".

The ratio of elastic design spectral acceleration calculated for Earthquake Ground Motion Level (EGML, In TBEC-2018 DD3 (The repetition period of the earthquake is 72 years) earthquake $\mathrm{S}_{\mathrm{ae}}(\mathrm{T})_{\mathrm{DD} 3}$ to the elastic design spectral acceleration calculated for earthquake ground motion level (EGML, in TBEC-2018 DD2 (The repetition period of the earthquake is 475 years) $S_{a e}(T)_{D D 2}$ is expressed by $\lambda$. к coefficient given in Table 1 is 1 for reinforced concrete buildings and 0.5 for steel buildings. The calculation of the effective relative story displacements according to relative story displacement $\left(\Delta_{i}^{\mathrm{X}}\right)$ determined for reduced seismic loads are given in Table 1. According to this, the maximum effective relative story displacements are given in Table 1 for reduced relative story displacement, connected infill walls and disconnected infill walls respectively.

\section{American Standard (ASCE 7-16)}

The parameters used for seismic design in ASCE 7-16 standard are similar to the parameters of TBEC-2018 standard. The measured spectral acceleration parameters $S_{s}$ and $S_{1}$ of the building site are taken from the interactive web application according to each site class. Later on, $F_{a}$ and $F_{v}$ coefficients are determined from its table in ASCE standard according to the coefficients of 1 second long period, 0.2 second short period and soil class. According to values in (ASCE-7-16), it is noticed that $F_{a}$ and $F_{v}$ coefficients are large for high quality soils and smaller for low quality soils. The spectral acceleration parameters of short period $S_{M S}$ and 1 second period $S_{M 1}$ are calculated according to the equation given in Table 1. The similarity with TBEC-2018 is so clear as shown. Later on, the design spectrum acceleration parameters SDS and SD1 are calculated as shown in Table 1. Here, a multiplier of 2/3 value is applied unlike TBEC-2018. In ASCE 7-16, 6 soil classes are defined like TBEC-2018, however nowadays studies are seeking for increasing the number of these classes. This is because the more the information are obtained about soil the higher accuracy is reached. Therefore, building designs are more real.

On the other hand, according to ASCE 7-16 buildings were classified with risk categories considering the occupancy aim and rate. Risk category in the standard are arrayed ascendingly from I to IV. For this study risk category was determined as II from its related table in the standard considering the category for "Buildings and other structures that represent high risk to human life in the event of failure". The importance factor of the building is determined according to the risk category. From the related table it is found that value is directly proportional to the increase in risk category as it varied between 1 and 1.50. Here from the related table and according to the risk category of $I I, l_{e}=1$ was chosen. In addition, the seismic design category determined according to $S_{D S}$ value from the related table changes from $A$ to $D$. A, B and C categories represent the cases of a one/two story separate houses and all the cases in which design spectral acceleration value doesn't meet the $S_{D S} \leq 0.50$ criteria. For such cases it is necessary to calculate the seismic load. For each $S_{D S}$ value bigger than 0.50 in the study the design category was determined as $\mathrm{D}$.

In ETABS (ETABS.v17) structure analysis program ASCE standard is already defined. With respect to TEC-2007, the difference about ASCE 7-16 is the existence of the approximate period concept. Before calculating the natural period of the building, the approximate period is calculated. The equation for approximate period is given in Table 1. Here in ASCE 7-16 standard according to the building type 5 values for $C_{t}$ and $x$ are given with a table format. For some of them where moment transferring steel frame systems are applied the values were given as $C_{t}=0.0724, x=0.8$, however for reinforced concrete system these values were suggested to be considered as $C_{t}=0.0466, x=0.9$. For other building that not included with the category at the related table, the values were suggested as; $C_{t}=0.0488, x=0.75$. Because of considering reinforced concrete frame buildings in this study, the values were accepted as; $C_{t}=0.0466, x=0.9$. $H_{N}$ value in the equation represents the total height of the building above the foundation level. Yet according to ASCE 7-16 there is a maximum period value for the approximate period that can't be exceeded. This value is calculated by multiplying with the coefficient of $C_{u}\left(1.7 \leq C_{u} \leq 1.4\right)$ chosen for the spectral acceleration parameter $S_{D 1}\left(0.1 \leq S_{D 1} \leq 0.4\right)$ according to the Table1. In addition, for moment transferring reinforced concrete and steel frames the approximate period value is calculated as $T_{a}=0.1 \mathrm{~N}$ like TEC-2007. But for the validation of this equation, the total height can't exceed $30 \mathrm{~m}$. $\mathrm{N}$ represents the number of stories. The equivalent seismic load calculation in ASCE 7-16 is run according to Table 1 (see ASCE 7-16). The equivalent seismic load calculation is applied for buildings with seismic design categories of $D, E$ and $F$ that don't include structural irregularity and their heights are less than $160 \mathrm{ft}(48 \mathrm{~m})$. Cs represents the seismic behavior factor which is calculated as shown in Table 1. W value represents the weight of the building. The weight of the building 
in TEC-2007 and TBEC-2018 was calculated by adding the dead load within the building and a certain ratio of the live load according to the occupancy of the building. Yet in ASCE 7-16, by disconsidering some cases the effective seismic weight is calculated on by the dead loads. As a result, the building weight considered in TEC-2007 and TBEC-2018 is larger than the building weight considered by ASCE 7-16. And this causes an increase in the base shear forces. The calculated $C_{s}$ must meet the criteria given in Table 1. In the American seismic standard both of the vertical and horizontal seismic loads are distributed on the building. This loads are transferred to the vertical elements of the building according to the rigidity of the elements. While the shear force of the story in vertical direction $\mathrm{F}_{\mathrm{x}}$ is calculated according to Table 1 , the vertical distribution factor $C_{v x}$ is calculated according to Table 1 . The total base shear force in Table 1 is represented by $V$. Here the effective seismic weight values are represented by $w_{i}$ and $w_{x}$. The parameter $k$ is defined as a force that related to the period. For buildings with $\mathrm{T} \leq 0.5 \mathrm{~s}, \mathrm{k}=1$. For buildings with $\mathrm{T} \geq 2.5 \mathrm{k}=2$. And for buildings with $0.5 \mathrm{sn}<\mathrm{T}<2.5 \mathrm{~s}$ $k$ is calculated by interpolation or directly accepted as 2 . The horizontal seismic force $V_{x}$ acting on each story is calculated as shown in Table 1. The calculated $\mathrm{V}_{\mathrm{x}}$ values are distributed on the vertical elements according to the rigidity ratios. The period considered in ETABS is calculated according to the maximum period limits values allowed by ASCE 7-16. For $C_{S}$ calculations it is considered that $T_{a}=T$ as defined in Table 1. After applying controls, if the equation in Table 1 is achieved then the period value found is accepted as the natural seismic period of the building. With respect to TEC2007, ASCE 7-16 applied more detailed limits and explanations for the calculation of the relative story displacement. The seismic load reduction factor $R_{a}$ in ASCE 7-16 is not multiplied with displacement values $(\Delta)$ unlike TEC-2007 and TBEC-2018. The calculation of the effective displacement $\left(\delta_{x e}\right)$ is applied by multiplying with the coefficient of $C_{d}=5.5$ as already shown in Table 1 . The relative story displacement values in ASCE 7-16 vary between $0.007 h_{s x} \leq \delta_{x} \leq 0.025 h_{s x}$ according to risk category and building type. Here story height is represented by $\left(h_{s x}\right)$. In this study, the relative story displacement value $\left(\Delta=0.020 \mathrm{~h}_{\mathrm{sx}}\right)$ that meet all the other buildings and risk II was applied.The summary of the common seismic design for TEC-2007, TBEC-2018 and ASCE 7-16 standards is described briefly in Figure 1.

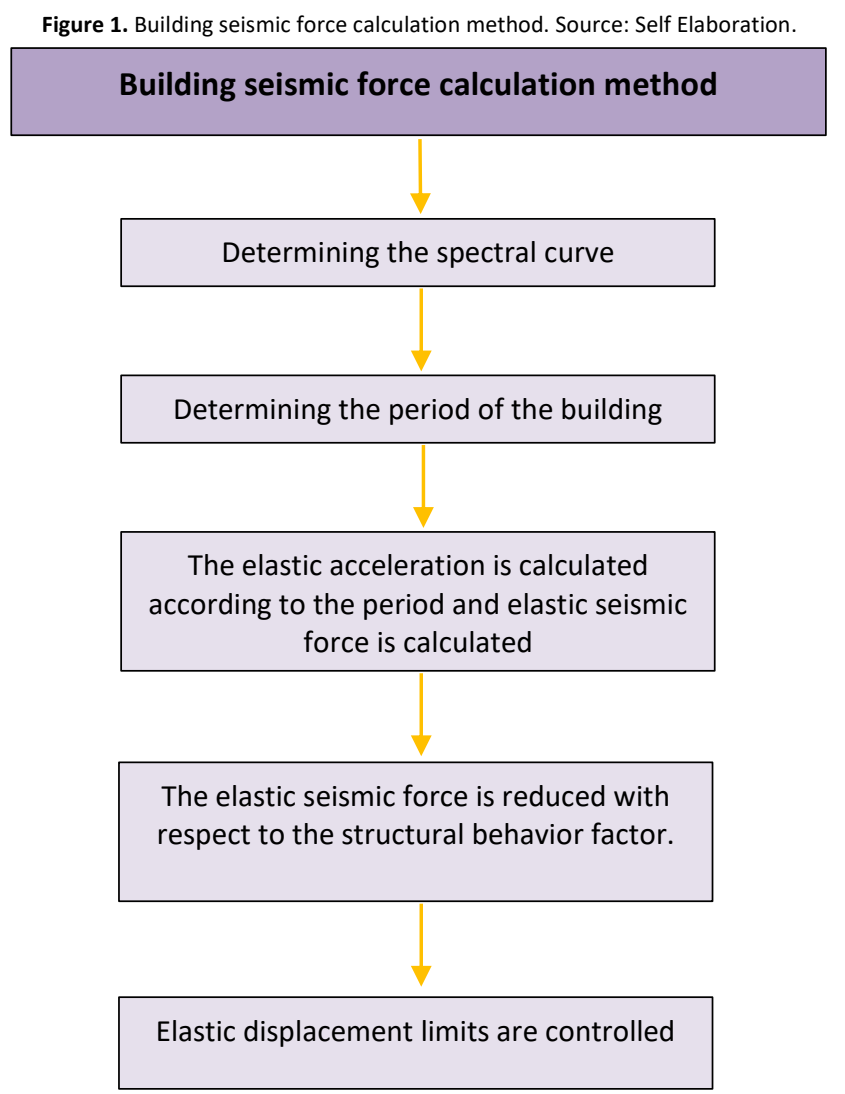

\section{Numerical Study}

In this study a comparison was carried out by considering ESL analyses according to TEC-2007, TBEC-2018 and ASCE 716 seismic standards for reinforced concrete frame residential building with story numbers of 3, 5, 7 and 9 that planned to be constructed in Avcilar district of Istanbul. According to the seismic ground motion, Avcilar zone is an important zone in Istanbul. While choosing the total building heights, the height limits in which ESLM are valid for TEC-2007, TBEC2018 ve ASCE 7-16 were considered as reference heights. In the model design by ETABS structural analysis program story height was accepted as 3.5 meters. The plan of the building is symmetric for both directions with a total area of $900 \mathrm{~m}^{2}$ the spaces between axes were chosen as $5 \mathrm{~m}$. 
As the building in Istanbul is located at 1. Seismic zone according to 2007 standards, the effective ground acceleration was considered within the calculations according to TBEC-2018 and ASCE 7-16. In addition, by considering the similarity between all stories the dimensions of columns, beams and slabs were chosen respectively as $500 \times 500 \mathrm{~mm}, 250 \times 500 \mathrm{~mm}$ and $150 \mathrm{~mm}$. The foundation was modeled as fixed. The concrete category of the determined structural system was chosen as C30. For the bearing system of the building, the seismic loads of the building were accepted to be carried by reinforced concrete frames of high ductility level as $R$ coefficient was 8 . The effects of the irregularities weren't considered as the bearing elements in the plan of each story were arrayed regularly (Figure 2).

In addition, the rigidity of the column sections are unsatisfied with respect to the increase in the story height, however this condition wasn't considered in this study. Because this study was applied only for comparing the different standards and the different soil classes. For building designs with total dead load and live load acting on the unit area of the floor in each story were chosen respectively as $g=2.2 \mathrm{kN} / \mathrm{m}^{2}$ and $\mathrm{q}=2.0 \mathrm{kN} / \mathrm{m}^{2}$ according to design load for building TS-498 (TS-498, 1997) and RC concrete code TS-500-2000 (TS-500-2000, 2000). The loads of a 200 mm-external infill wall and a $100 \mathrm{~mm}$ internal wall acting at each story were chosen respectively as $g_{d}=12 \mathrm{kN} / \mathrm{m}, g_{d}=9 \mathrm{kN} / \mathrm{m}$. For all comparisons applied a disconnection between infill walls and frame system was considered. This means that wall load acts on the building only as a dead load. Therefore, it was considered that the wall has no effect on the lateral rigidity. In Figure 2 , the story plan and 3D models of the considered buildings were given. While Table 1 shows the seismic design parameters according to different standards, Table 2 shows the basic parametric values for the spectrum curves.

Figure 2. The plan and 3D views for the designed buildings. Source: Self Elaboration.

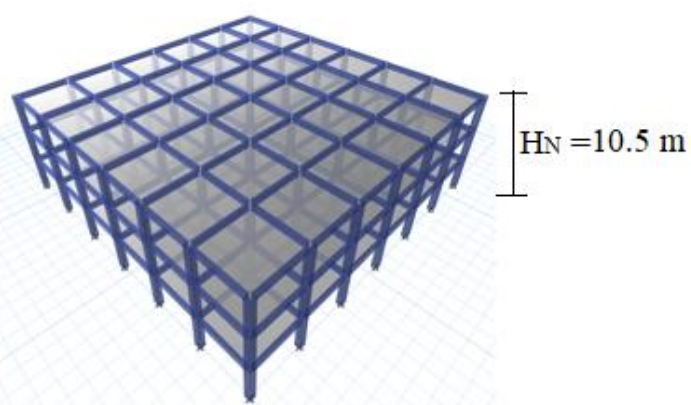

a) 3-story

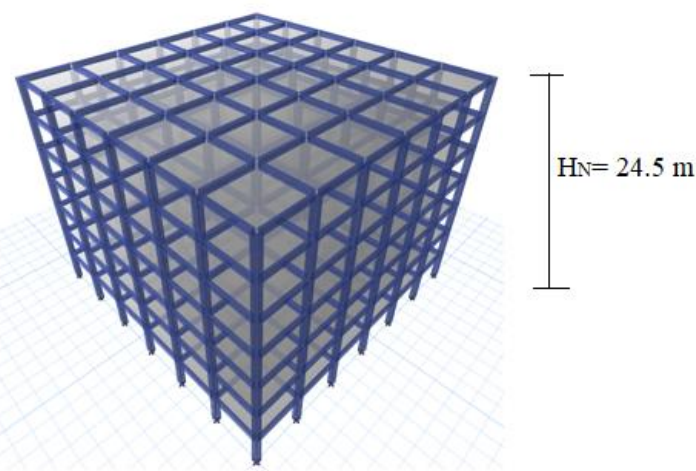

c) 7-story

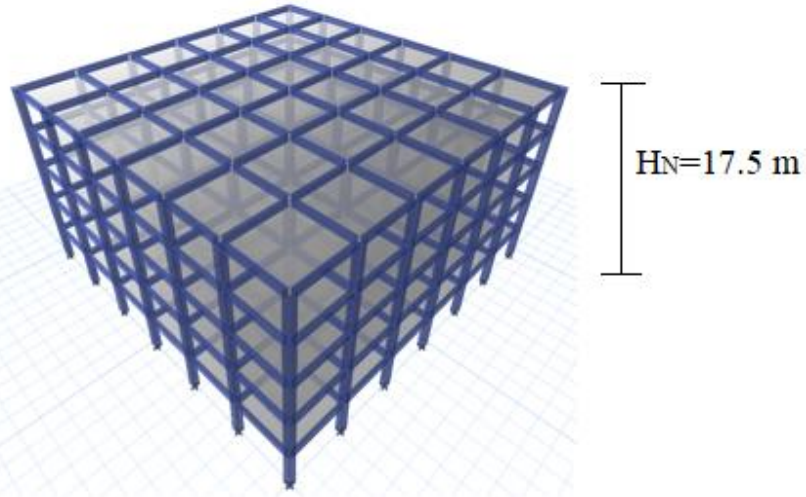

b) 5-story

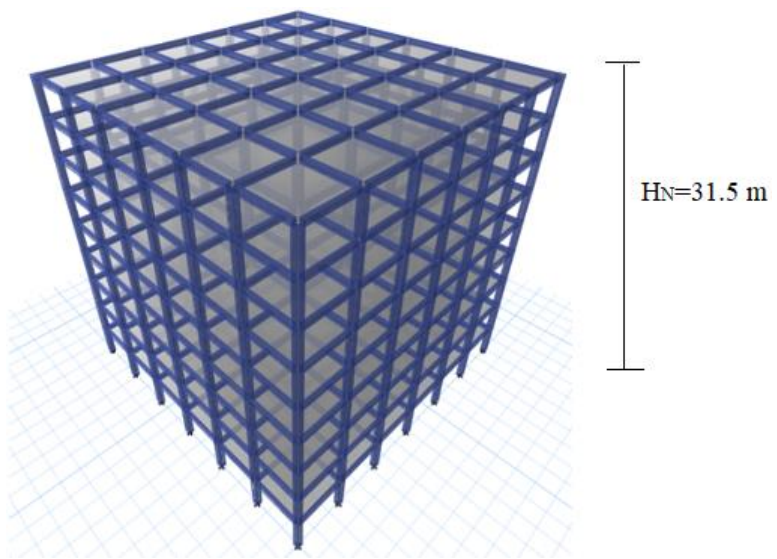

d) 9-story 
Table 2. TEC-2007, TBEC-2018 and ASCE 7-16 Earthquake Load Calculation Parameters. Source: Self Elaboration.

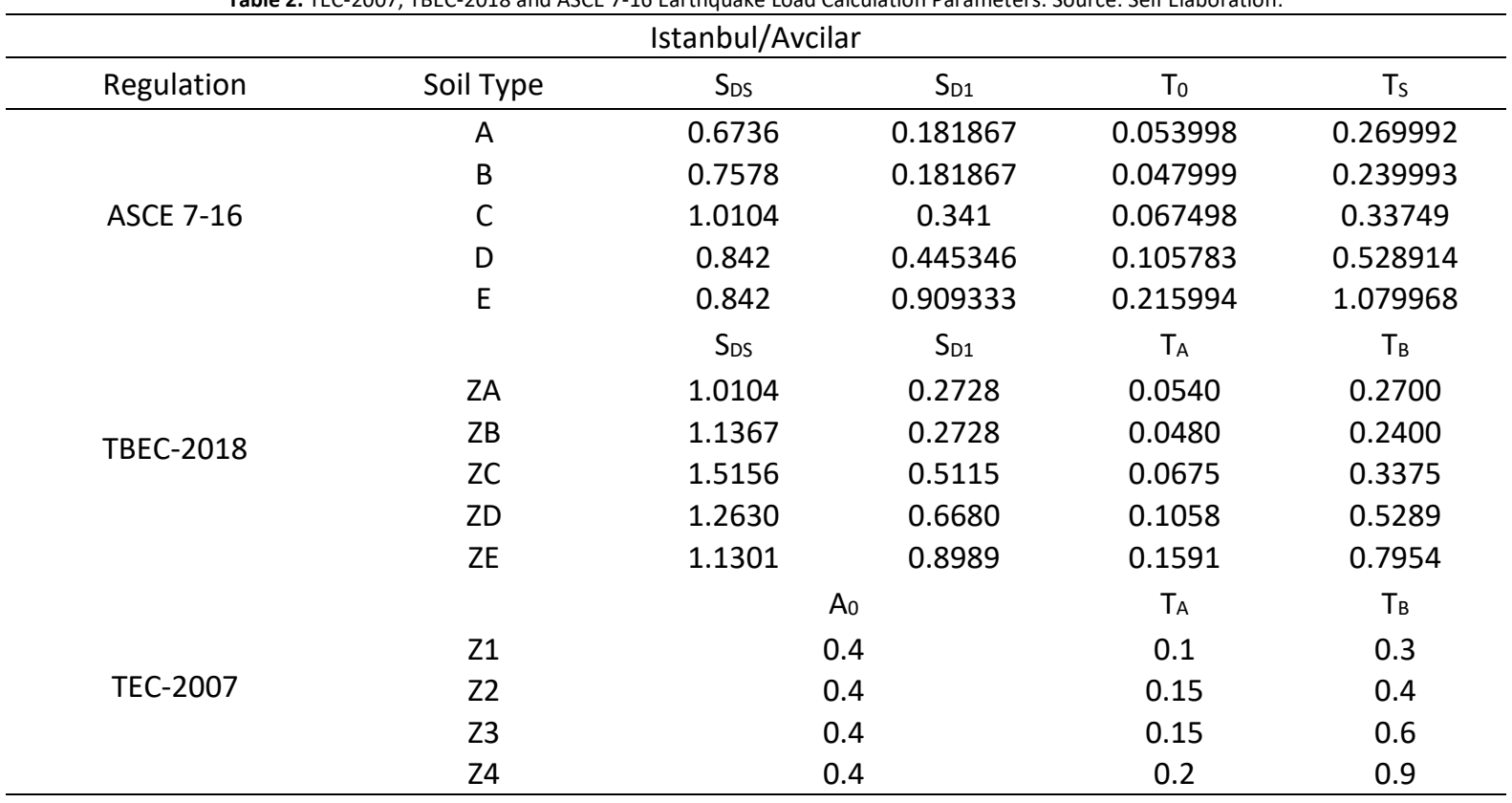

Table 3.Comparison between standards for spectral acceleration coefficients according to the design earthquake (DD-2) of the chosen provinces. Source: Self Elaboration

\begin{tabular}{|c|c|c|c|c|c|c|c|c|c|c|c|c|}
\hline \multirow{3}{*}{$\begin{array}{c}\text { Design } \\
\text { Earthquake }\end{array}$} & \multicolumn{2}{|c|}{ TEC-2007 } & \multicolumn{10}{|c|}{ TBEC-2018 } \\
\hline & \multicolumn{2}{|c|}{ Z1-Z2-Z3-Z4 } & \multicolumn{2}{|c|}{ ZA } & \multicolumn{2}{|c|}{ ZB } & \multicolumn{2}{|c|}{ ZC } & \multicolumn{2}{|c|}{ ZD } & \multicolumn{2}{|c|}{ ZE } \\
\hline & $0.4 * S_{D S}$ & SDS & $0.4 * S_{D S}$ & $\mathrm{~S}_{D S}$ & $0.4 * S_{D S}$ & SDS & $0.4 * S_{D S}$ & SDS & $0.4 * S_{D S}$ & SDS & $0.4^{*} S_{D S}$ & SDS \\
\hline \multirow[t]{5}{*}{ Avcilar } & 0.4 & 1 & 0.404 & 1.01 & 0.45 & 1.13 & 0.606 & 1.51 & 0.505 & 1.26 & 0.452 & 1.13 \\
\hline & \multirow{2}{*}{\multicolumn{2}{|c|}{$\begin{array}{l}\text { Design } \\
\text { Earthquake }\end{array}$}} & \multicolumn{10}{|c|}{ ASCE 7-16 } \\
\hline & & & \multicolumn{2}{|c|}{ A } & \multicolumn{2}{|l|}{ B } & \multicolumn{2}{|c|}{ C } & \multicolumn{2}{|c|}{ D } & \multicolumn{2}{|c|}{$\mathrm{E}$} \\
\hline & \multirow{2}{*}{\multicolumn{2}{|c|}{ Avcilar }} & $0.4 * S_{D S}$ & $S_{D S}$ & $0.4 * S_{D S}$ & SDS & $0.4 * S_{D S}$ & SDS & $0.4 * S_{D S}$ & SDS & $0.4 * S_{D S}$ & SDS \\
\hline & & & 0.269 & 0.67 & 0.302 & 0.75 & 0.404 & 1.01 & 0.336 & 0.84 & 0.336 & 0.84 \\
\hline
\end{tabular}

The spectral acceleration values and the dominant soil periods of Istanbul Avcilar district were determined according to TEC-2007, TBEC-2018 and ASCE 7-16 standards. The values of Avcilar district related to TEC-2007 were determined according to the effective ground acceleration because of being into 1 . Seismic zone. The values related to TBEC-2018 were obtained from the seismic acceleration map exists at the website of AFAD (AFAD, 2017) corporation by choosing the center coordinates of the related district. The values related to ASCE 7-16 were calculated by applying the equations of spectrum curve in ASCE 7-16 on the data obtained from the page of AFAD. With respect to Table 1 while SDS values of ASCE 7-16 in A, B, C and D soil types represent $66.7 \%$ of the values related to TBEC-2018, the value of SDS value of ASCE 7-16 in E soil type represents $74.5 \%$ of the value related to TBEC-2018. This is because the change in $F_{a}$ value according to the soil type. For more detailed explanation, the design spectrum curves of the related zone for DD2 seismic ground motion level were shown in Figure 3 into different sets for each soil class. In addition, with respect to Table 3, while the 
spectral acceleration coefficients of the same seismic zone are constant for different soil classes according to TEC-2007, these coefficients change for different soil according to TBEC-2018 and ASCE 7-16. For TBEC-2018 the weaker the soil type becomes, the higher the acceleration coefficients are obtained. For ASCE-7-16, even in the weakest soil the value of TEC-2007 $(0.4 *$ SDS $)$ can't be reached. Furthermore, after C soil type the coefficients begin to decrease. Therefore, applying ASCE 7-16 standard can result in more economical sections according to the other standards.

Figure 3. The combined design spectrum curves of the related zone for DD2 seismic ground motion level according to all soil types.Source: Self Elaboration
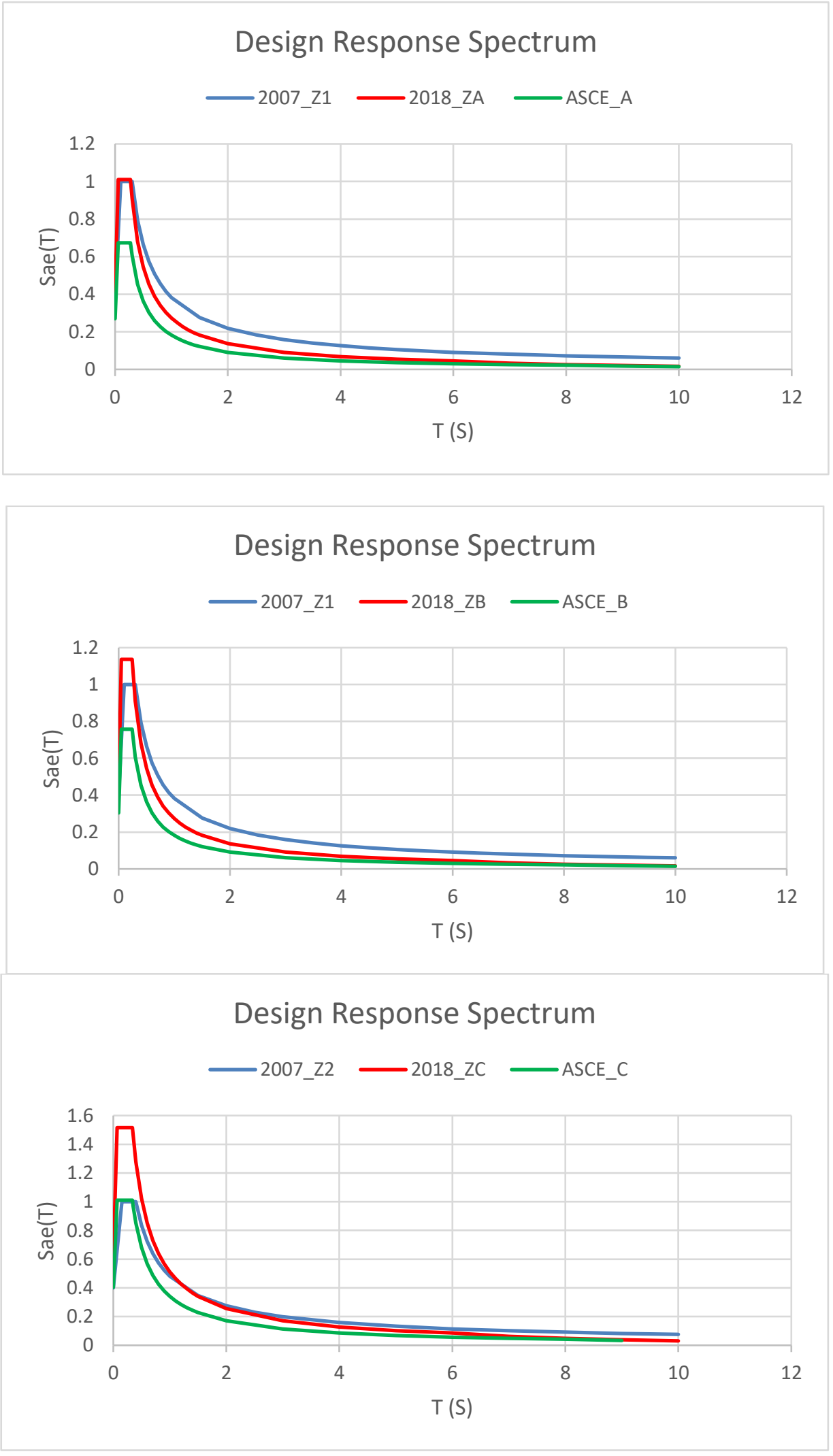


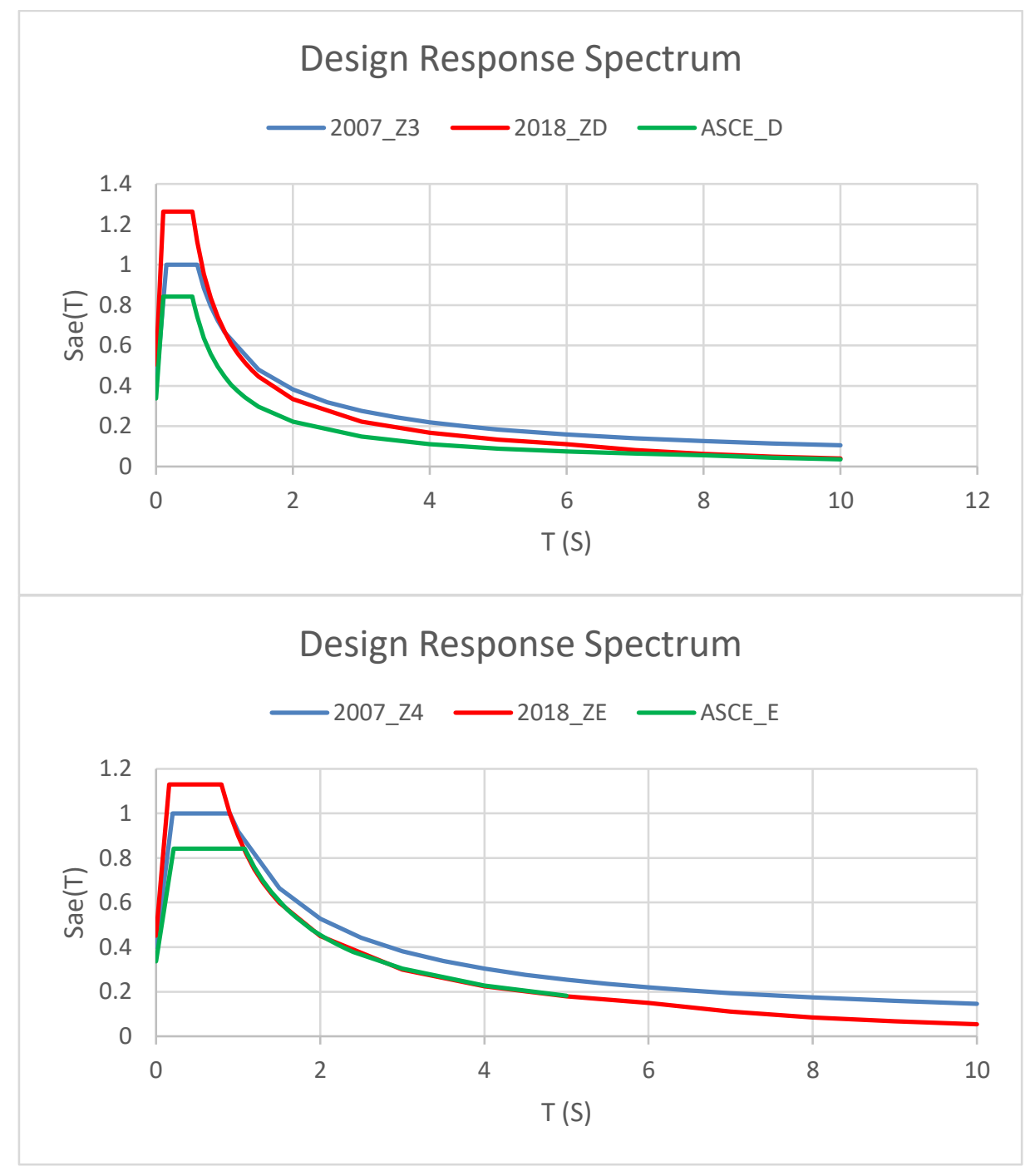

The spectral acceleration coefficient of Avcilar restrict of Istanbul which located in 1. Seismic zone according to TEC 2007 got a maximum value with TBEC-2018 in ZC soil class with $50 \%$ increase ratio. On the other hand, for ASCE 7-16 while in $C$ soil type the spectral acceleration coefficient was almost equal to the coefficient obtained by TEC-2007, in the other soil types it was lower than the other two standards. While the dominant soil periods $T_{A}$ and $T_{B}$ change in TEC-2007 only according to site classes, in TBEC-2018 and ASCE 7-16 these values change also according to the seismic zones. For the same zone and according to TEC-2007, TBEC-2018 and ASCE 7-16 the weaker the site class gets the larger the plateau between the dominant soil periods gets. Except for Z4 (ZE-E) soil class where the increase at TEC-2007 is higher than the increases of the other two standards.

Residential buildings of 3, 5, 7 and 9 stories were compared according to TEC-2007, TBEC-2018 and ASCE 7-16 in different soil classes by arraying the bearing elements regularly in the story plan of reinforced concrete frame structural buildings. All the comparisons were represented by figures and tables into sets. Figure 4 shows the base shear forces of the analyzed buildings for 5 different soil class. Figure 5 shows the relative story displacements. While the maximum relative story displacement was determined for TEC-2007 and ASCE as 0.02, this value was determined for TBEC-2018 as 0.016 . Table 3 compares spectral acceleration coefficients. 
Figure 4. The base shear forces according to soil class for residential buildings with different heights. Source: Self Elaboration.
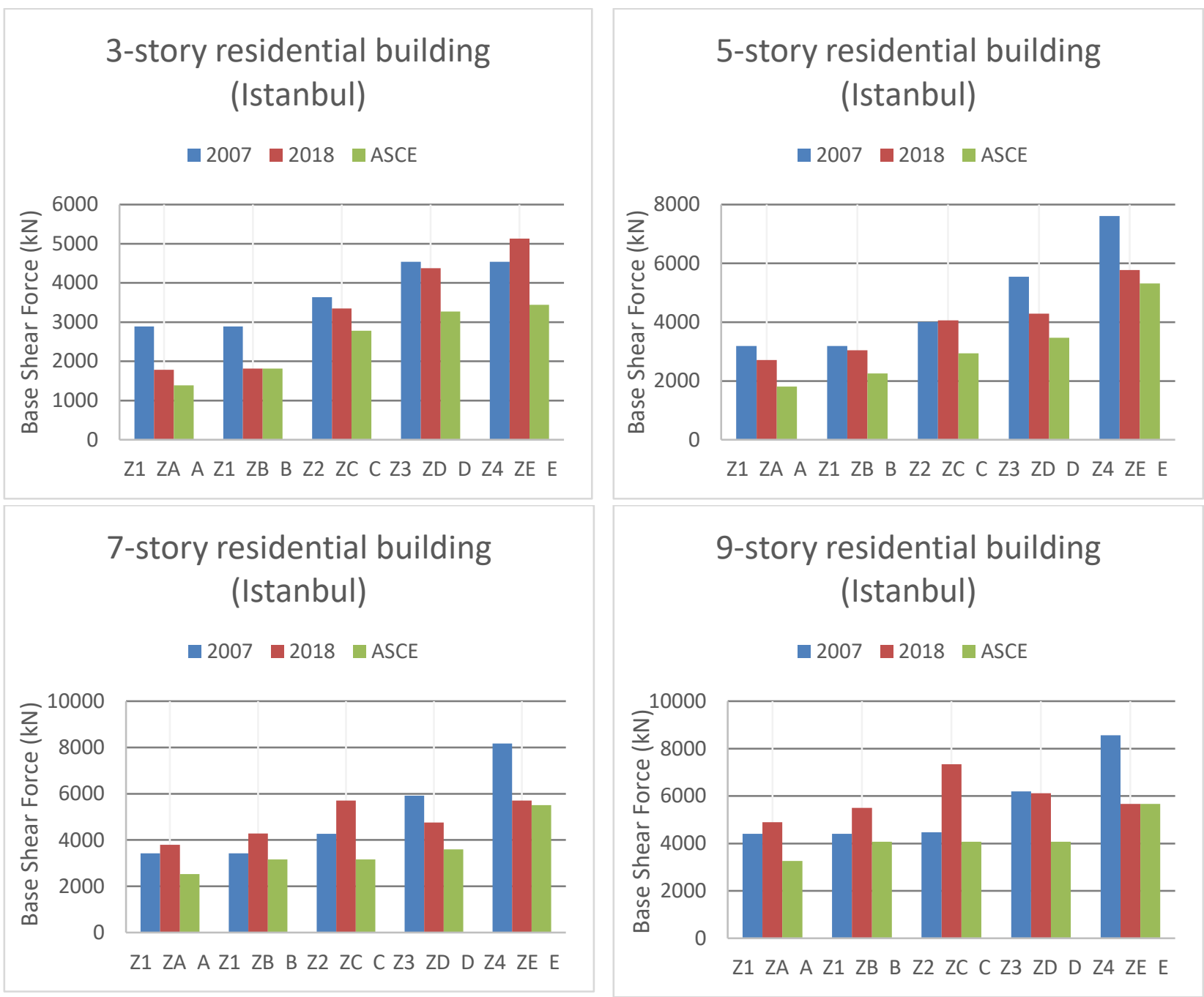

Figure 5.The relative story displacement values according to soil class for residential buildings with different heights. Source: Self Elaboration
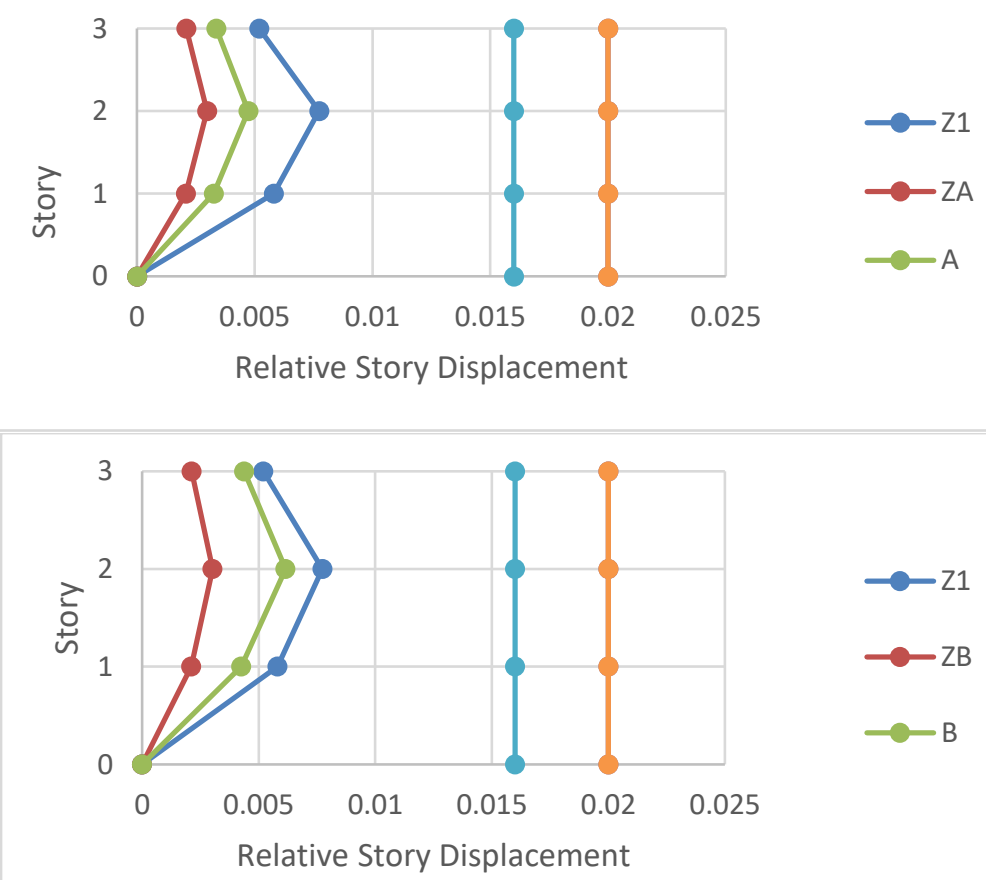

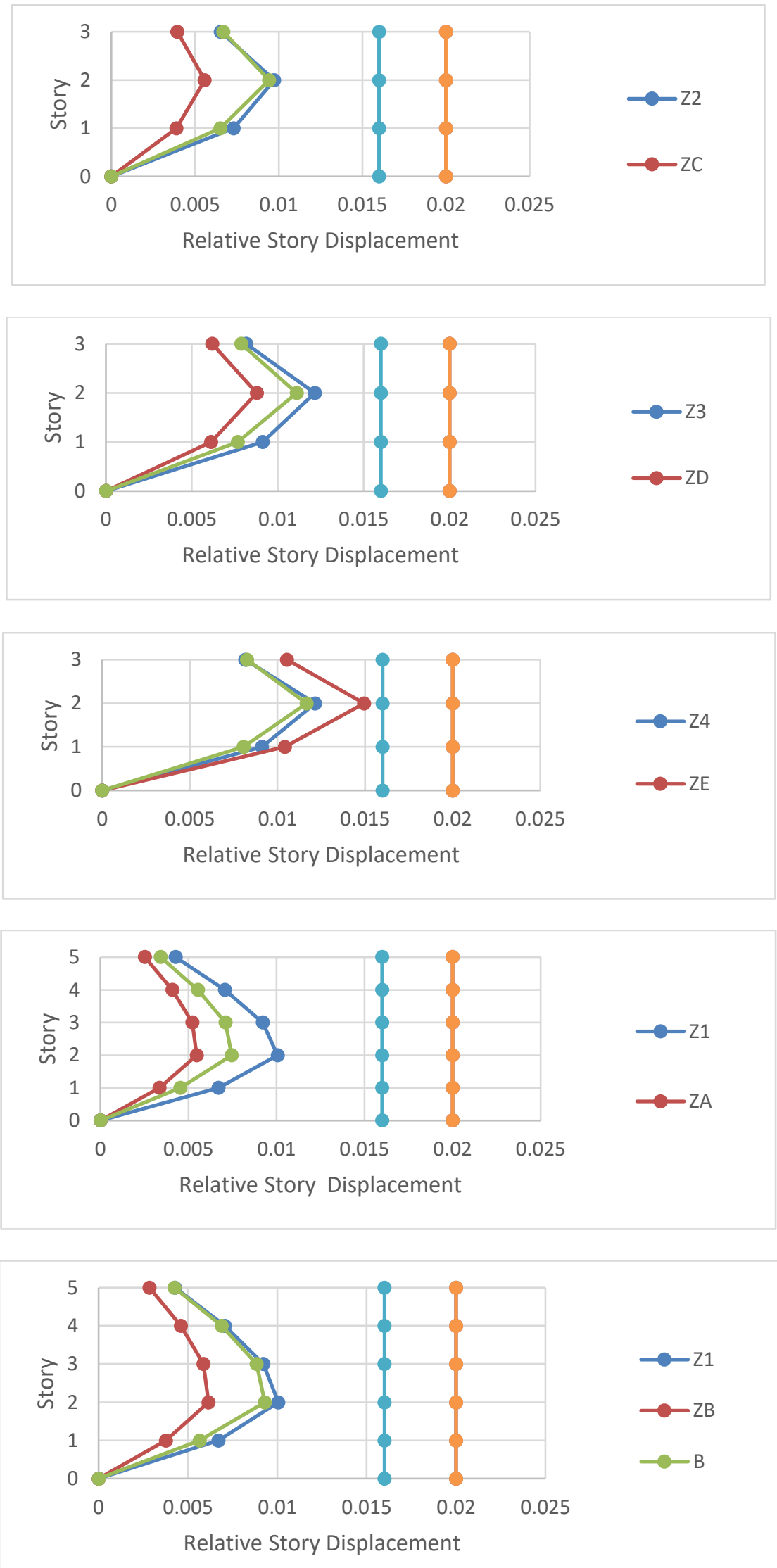

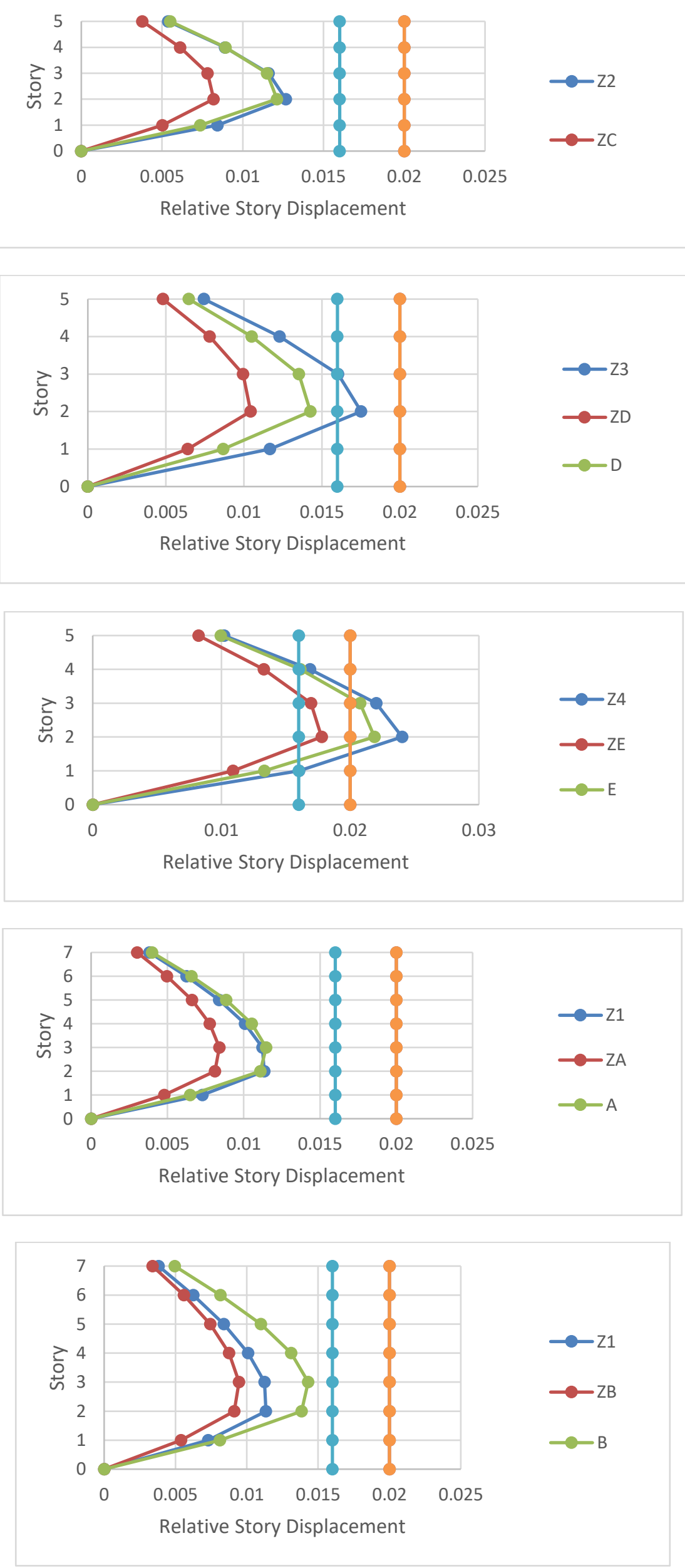

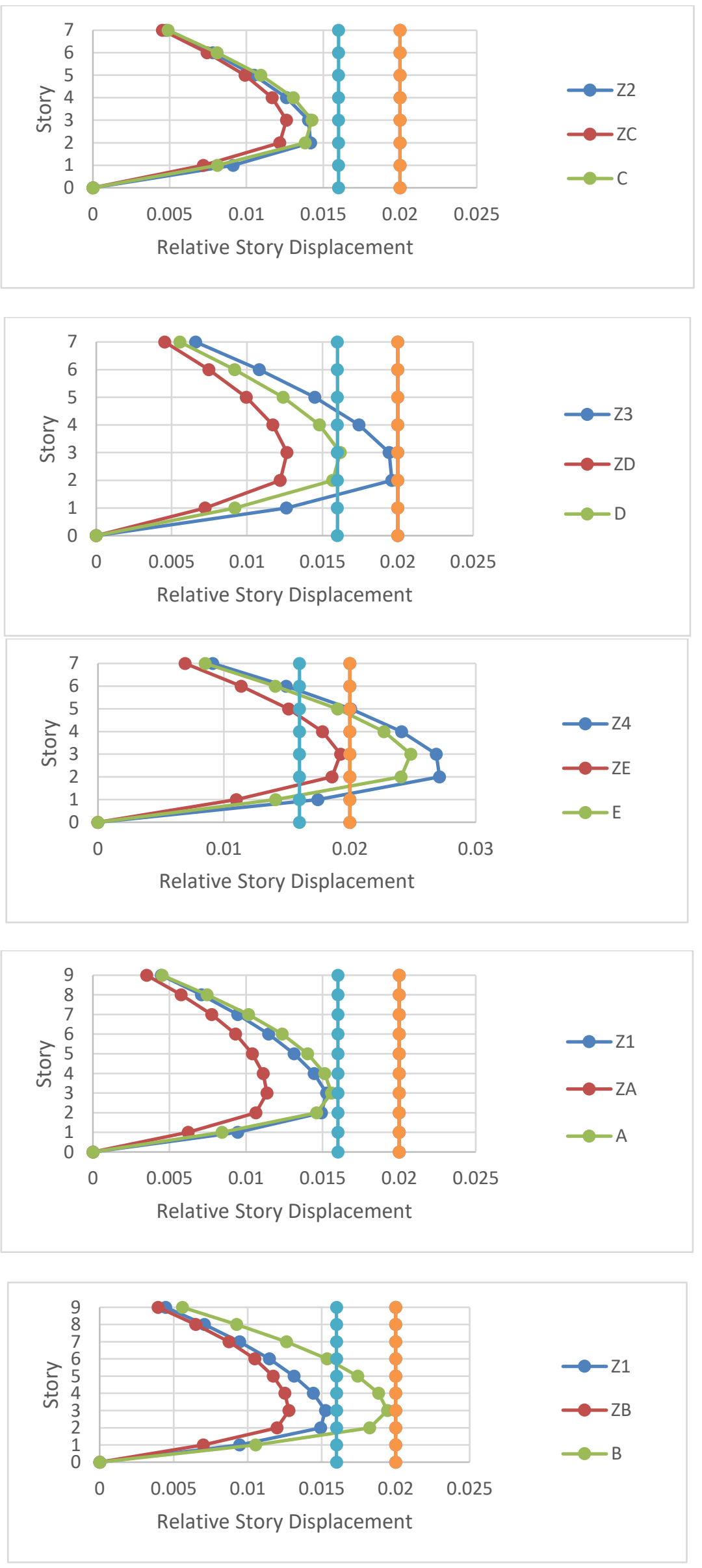


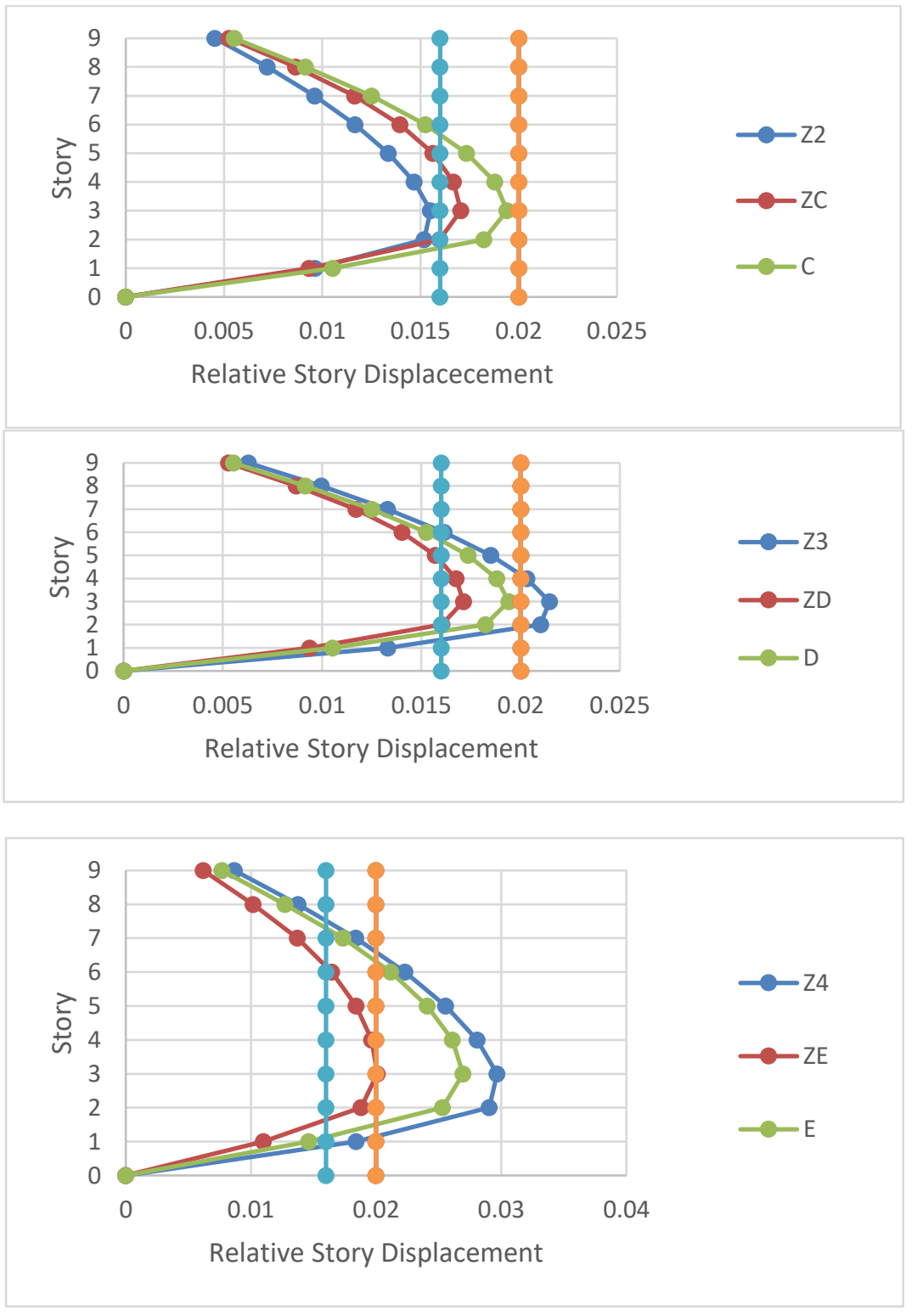

Table 4. Building analysis results according to TEC-2007, TBEC-2018 and ASCE 7-16. Source: Self Elaboration.

\begin{tabular}{|c|c|c|c|c|c|c|c|c|c|}
\hline \multirow{3}{*}{$\begin{array}{l}\text { Earthquake } \\
\text { direction } \\
\text { considered }\end{array}$} & \multirow{3}{*}{$\begin{array}{l}\text { Structure } \\
\text { Weight } \\
\text { (kN) }\end{array}$} & \multirow{3}{*}{$\begin{array}{l}\text { Number } \\
\text { of floor } \\
\text { (Total } \\
\text { building } \\
\text { height) }\end{array}$} & \multicolumn{5}{|c|}{ Natural Vibration Period (s) } & \multicolumn{2}{|c|}{ Ratio } \\
\hline & & & \multirow{2}{*}{$\begin{array}{c}\text { TEC-2007 } \\
\text { Z1-Z2Z3-Z4 }\end{array}$} & \multicolumn{3}{|c|}{ ASCE 7-16 } & \multirow{2}{*}{$\begin{array}{l}\text { TBEC- } \\
2018 \\
\text { ZA-ZE }\end{array}$} & \multirow{2}{*}{$\begin{array}{c}\text { Ratio }^{1} \\
\text { TBEC/TEC }\end{array}$} & \multirow{2}{*}{$\begin{array}{c}\text { Ratio }^{2} \\
\text { TBEC/ASCE }\end{array}$} \\
\hline & & & & A & B & C-D-E & & & \\
\hline$X$ and $Y$ & 35239.3 & $3(10.5 \mathrm{~m})$ & 0.528 & 0.594 & 0.57 & 0.542 & 0.693 & 1.31 & 1.27 \\
\hline $\mathrm{X}$ and $\mathrm{Y}$ & 58732.3 & $5(17.5 m)$ & 0.891 & 0.941 & 0.902 & 0.858 & 1.185 & 1.32 & 1.38 \\
\hline $\mathrm{X}$ and $\mathrm{Y}$ & 82225.2 & $7(24.5 m)$ & 1.258 & 1.274 & 1.221 & 1.161 & 1.682 & 1.33 & 1.44 \\
\hline$X$ and $Y$ & 105718.1 & $9(31.5 \mathrm{~m})$ & 1.627 & 1.598 & 1.531 & 1.456 & 2.181 & 1.34 & 1.49 \\
\hline
\end{tabular}

The period values according to TEC-2007, TBEC-2018 and ASCE 7-16 standards obtained by neglecting the existence of fill walls are given in Table 4. It is requested by TBEC-2018 and ASCE 7-16 to consider the effective section rigidities. Although the effective section rigidities were considered, 2018 standard and the other two standards caused respectively significant increases in the first natural seismic period of the building and in the relative story displacements. Despite the similarity between TBEC-2018 and ASCE 7-16 about applying the effective section rigidities, it was observed that the minimum period value is suggested by ASCE 7-16 (Santos, Zanaica, Bucur, Lima, \& Arai, 2013; 
Vijay, Yogendra, \& Dominik H. L., 2012). However the effective section rigidities weren't consider in 2007 standard, it caused period values that are almost equal to those of ASCE 7-16 standard. In addition, it was found that for the weaker soil of the 1. Seismic zone located in Istanbul Avcilar and more story numbers the shear forces obtained by ASCE 7-16 were lower that those of the other two standards. While the maximum base shear forces for building with 3 and 5 stories were obtained by TEC-2007, for buildings with more stories as 7 and 9 stories the maximum values were obtained by TBEC-2018. During analysis of high buildings it was concluded that the design forces of high buildings increase significantly by TBEC-2018 in strong soils, and by TEC-2007 in weak soils.

\section{Performance evaluation with nonlinear pushover analysis}

In parallel with the development of earthquake engineering in the world, the Turkish Earthquake Code was introduced for the first time in 2007 (in TEC-2007) with the title of performance analysis of existed buildings. TBEC-2018, prepared with substantially similar conditions with ASCE 7-16, has expanded the scope of the performance analysis section in TEC-2007 and caused restrictions that have been introduced for the new buildings to be built. In TBEC-2018, two methods, which are linear elastic and non-linear, are proposed to evaluate the seismic performance of buildings. By comparing the internal forces calculated in the linear method with the capacities, the effect-capacity ratios are calculated. In nonlinear method, it is necessary to calculate deformations obtained under nonlinear loadings in critical sections of structural elements. In the pushover analysis, the base shear force and deformations under this force are calculated, and the performance point calculation of the building is made according to the displacement coefficient method in the possible earthquake using the load displacement graph and the elastic spectrum graph (demandresponse graphs).

Unit deformations (strains) on concrete and reinforcement rebars in cross sections at the relevant performance level are compared with limit unit deformation values depending on performance levels. In determining the performance level in accordance with the regulations given in TBEC-2018, field information (concrete compressive strength, soil properties, reinforcement properties, foundation type, similarity of the building to the existing project, etc.) are required for the creation and modeling of the three-dimensional model of the building. According to the performance analysis performed, the buildings are grouped at 4 different performance levels according to the distribution of damages and the type of damages. Four performance levels, O, IO, LS and CP are considered as specified in this code and several other international guidelines such as FEMA-356, ATC-40 and FEMA-440. The "O" level depict that no damage, "IO" level implies very light damage with minor local yielding and negligible residual drifts. "LS" defines the limit of the behavior beyond elasticity that the section is capable of safely ensuring the strength, while the "CP" level is associated with extensive inelastic distortion of structural members with little residual strength and stiffness (Figure 6).

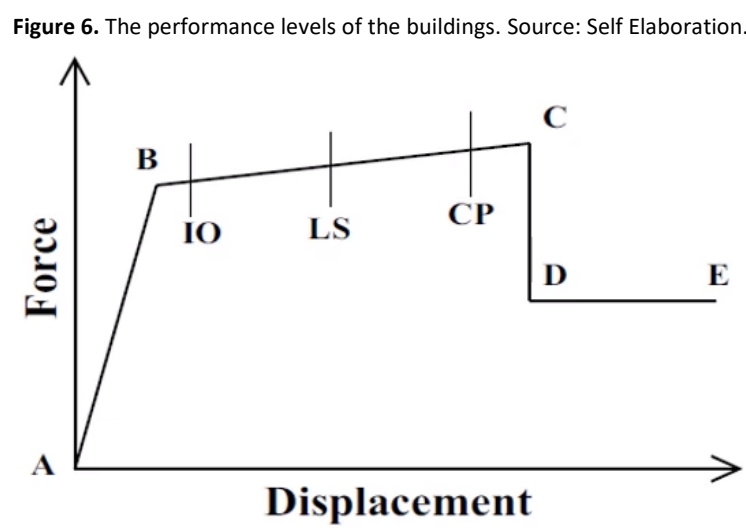

In these two methods (linear elastic and non-linear) incremental Equivalent Seismic Load Method and Modal Anaysis can be used. In selection of these, especially the number of floors and irregularity coefficient $\left(n_{b i}\right)$ is important. Moreover, in accordance with the earthquake taken into consideration, the ratio of the active mass of the primary (dominant) vibration mode calculated taking the linear elastic behavior as a basis point to the total mass of the building (except for the masses of the basement floors covered by the rigid frames) should be above 0.70 (TEC, 2007 ; TBEC2018). In the performance analysis used in this section of the study, the main steps and assumptions are given in the following;

1) Cracked section of columns and beams are determined by analyzing bearing system under the vertical loads ( $G$ and Q). 
2) Beam and column elements are modeled as nonlinear frame elements with lumped plasticity by defining plastic hinges at both ends of the beams and columns.

3) To define plastic hinge properties, moment-curvature analyses are carried out taking section properties and axial load level for every column and beams into account.

4) The input required for the above mentioned programs is moment-rotation instead of moment curvature therefore transformation is needed. Transformations of bilinear diagrams $\mathrm{M}-\varphi$ (Moment-curvature) which are obtained in aforementioned procedure, in bilinear diagrams $M-\phi$ (Moment-rotations) implements.

5) In this step, a suitable plastic hinge length $L_{p}$ is used to obtain ultimate rotation values from the ultimate curvatures. According to the codes plastic hinge length $L_{p}$ is selected as half section effective height (0.5h).

6) After completing plastic hinge length and effective flexural stiffness values, the vertical loads $(g+0.3 q)$ are applied on the systems. 0.3 is the live load participation factor. The pushover analysis takes from the gravity loads and a monotonically increasing pattern of lateral static forces. The first mode shape (inverted triangular) has been selected for loading as general. In the analysis, $\mathrm{P}-\Delta$ effects were taken into account.

7) In order to obtain lateral load - lateral top displacement curve of the model buildings, static pushover analysis method is selected.

8) Static pushover curvature is obtained by analyzing bearing system under the vertical loads and proportional incremental interval seismic loads. This pushover curvature is converted to capacity diagram.

9) The capacity curves of the buildings for two directions (similar) are obtained by static pushover analysis, and performance points are determined as seen in Figure 7.

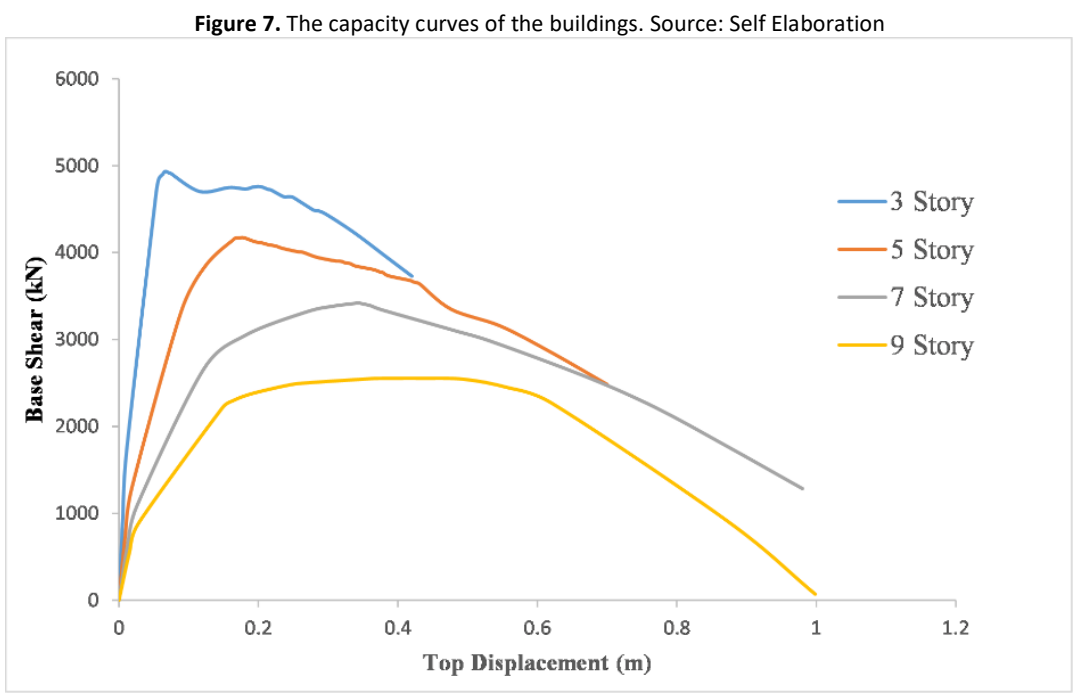

10) Design earthquake is converted to spectrum curve and modal displacement demand is determined. The plastic hinges are obtained by pushing again the bearing system up to this demand. The design earthquake, for which the possibility to be exceeded in 50 years is $10 \%$, is considered in the analysis. Nonlinear static pushover analysis is determined by SAP 2000 v.22.1 (Sap 2000, 2020).

11) Capacity curves obtained by the use of pushover analysis are transformed from base shear $\&$ top displacement coordinate converted into spectral displacement \& spectral acceleration $\left(\mathrm{S}_{a} \& \mathrm{~S}_{d}\right)$ curves. In the Figure 8 , graphical representation of expected seismic performance of the models by the intersection of capacity curve with an elastic response spectrum obtained from codes for soil and earthquake zonations. 


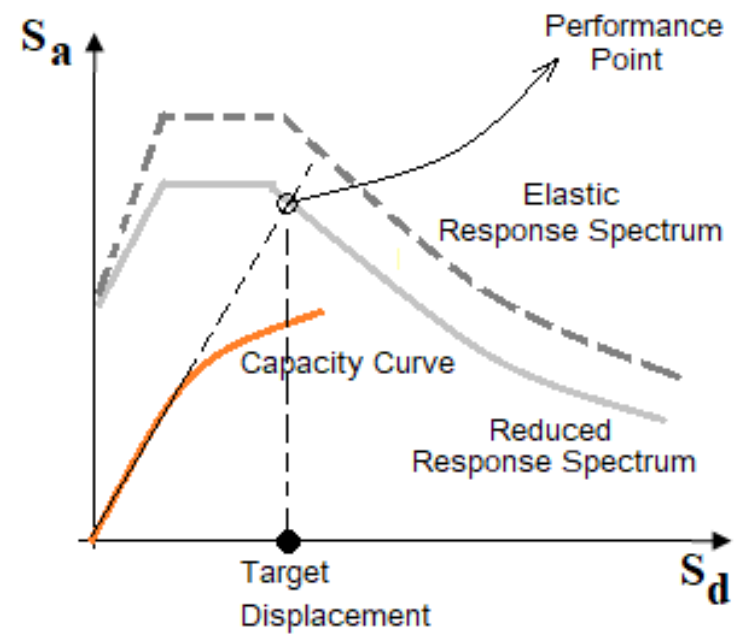

12) The intersection is the performance point, and the base shear and displacement obtained at intersection point are the maximum estimated value for given earthquake ground motion.

13) Until the building reaches the failure displacement, the damages that occur in the structural members and the distribution of these damages in the buildings are checked in accordance with the capacity design criteria. Figure 9 shows the plastic hinge locations occur at the yielding displacement in the model 3,5,7 and 9 story buildings, respectively.

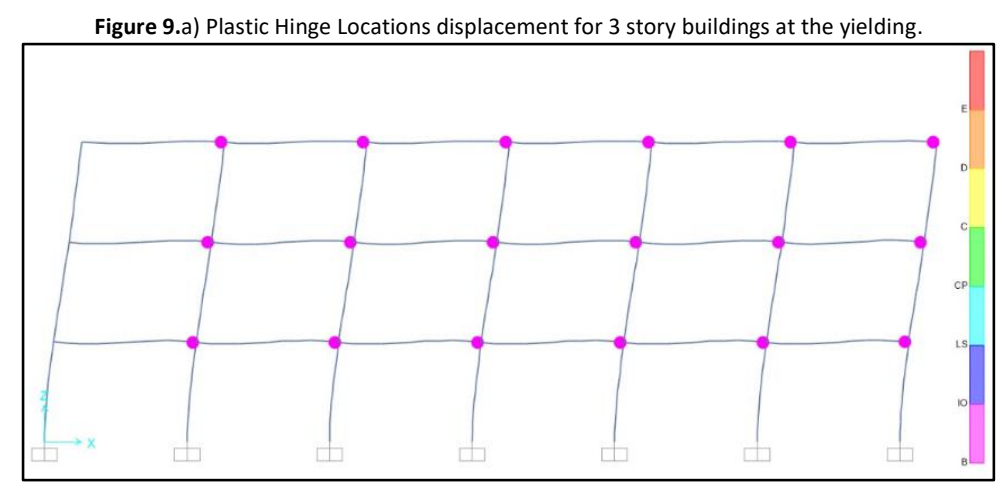

b) Plastic Hinge Locations displacement for 5 story buildings at the yielding

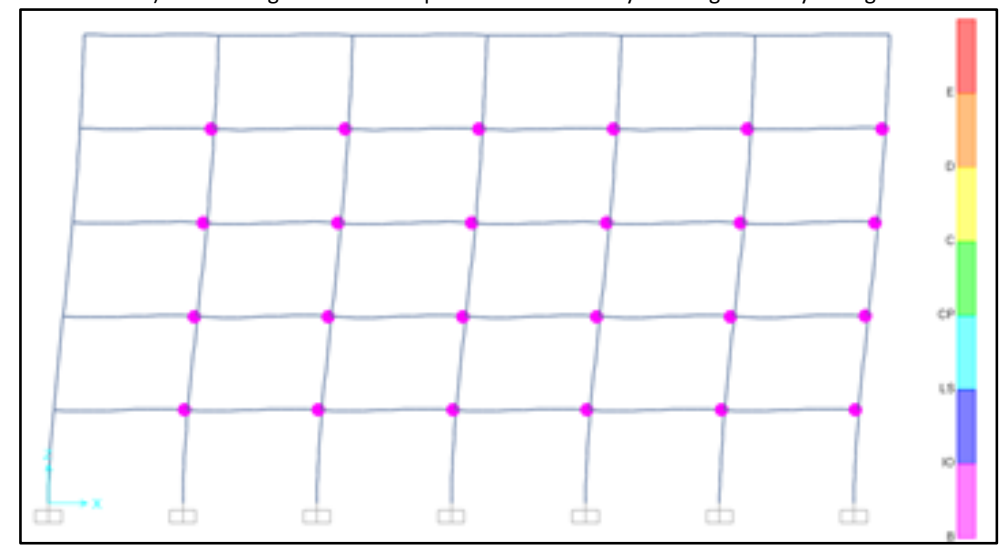


c) Plastic Hinge Locations displacement for 7 story buildings at the yielding

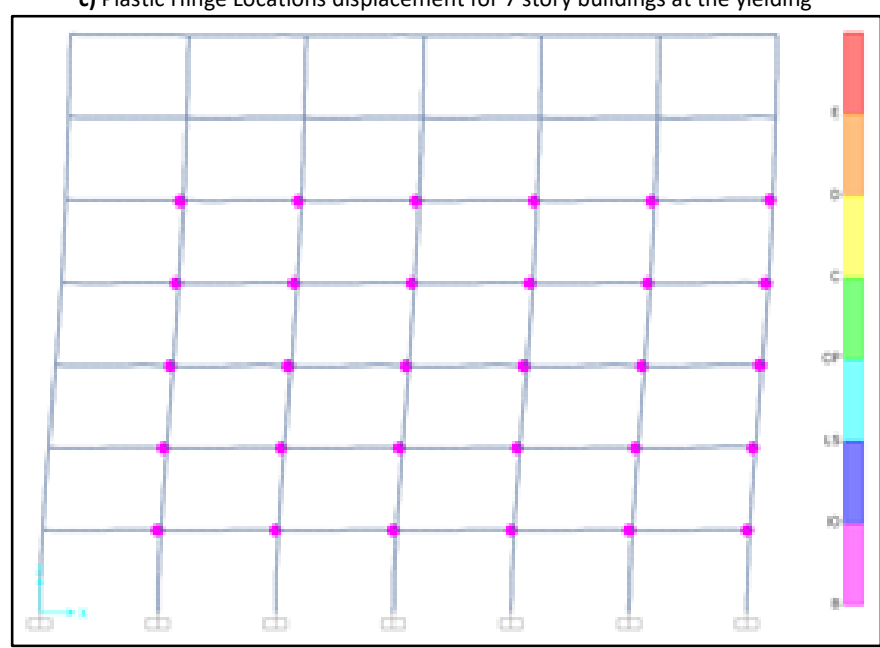

d) Plastic Hinge Locations displacement for 9 story buildings at the yielding

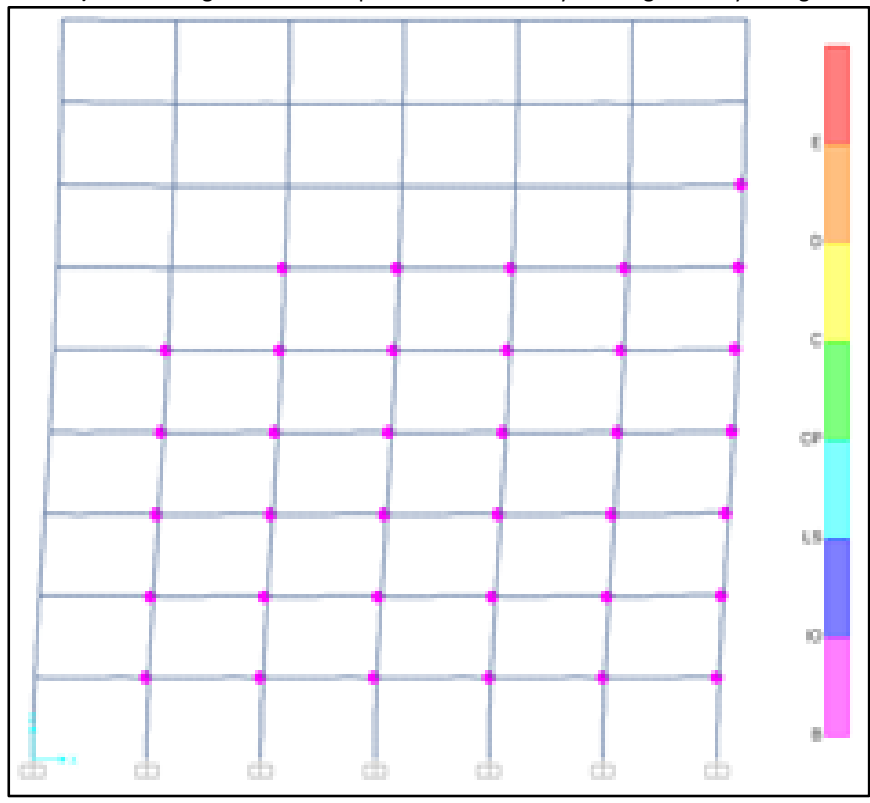

Performance analysis of four different models (3, 5, 7 and 9 floors) was made according to the calculation procedure summary mentioned above. Performance points are determined by intersecting the capacity curves and the reduced response acceleration spectrum. Performance displacement values $(\mathrm{m})$ for TEC-2007, TBEC-2018 and ASCE 7-16 are given in Table 5, 6 and 7, respectively.

Table 5.Performance Displacement for TEC-2007. Source: Self Elaboration

\begin{tabular}{|c|c|c|c|c|}
\hline \multirow{2}{*}{$\begin{array}{c}\text { Number of floor } \\
\text { (Total building } \\
\text { height) }\end{array}$} & \multicolumn{4}{|c|}{ Performance (Target)Displacement (m) } \\
\cline { 2 - 5 } & \multicolumn{4}{|c|}{ TEC-2007 (Design Earthquake) } \\
\hline $3(10.5 \mathrm{~m})$ & 0.0756 & 0.0756 & 0.1145 & Z4 \\
\hline $5(17.5 \mathrm{~m})$ & 0.1421 & 0.1527 & 0.1876 & 0.2947 \\
\hline $7(24.5 \mathrm{~m})$ & 0.2249 & 0.2643 & 0.3371 & 0.3983 \\
\hline $9(31.5 \mathrm{~m})$ & 0.4008 & 0.4330 & 0.4914 & 0.5211 \\
\hline
\end{tabular}


Table 6.Performance Displacement for TBEC-2018. Source: Self Elaboration

\begin{tabular}{|c|c|c|c|c|c|}
\hline \multirow{2}{*}{$\begin{array}{c}\text { Number of } \\
\text { floor } \\
\text { (Total building } \\
\text { height) }\end{array}$} & \multicolumn{5}{|c|}{ Performance (Target) Displacement (m) } \\
\cline { 2 - 6 } & TBEC-2018 (Design Earthquake-DD2) \\
\hline & ZA & ZB & ZC & ZD & ZE \\
\hline $3(10.5 \mathrm{~m})$ & 0.0756 & 0.0793 & 0.1246 & 0.1911 & 0.1993 \\
\hline $5(17.5 \mathrm{~m})$ & 0.1421 & 0.1589 & 0.1961 & 0.3012 & 0.3017 \\
\hline $7(24.5 \mathrm{~m})$ & 0.2063 & 0.2472 & 0.3384 & 0.3671 & 0.3835 \\
\hline $9(31.5 \mathrm{~m})$ & 0.3874 & 0.4113 & 0.4973 & 0.5045 & 0.5009 \\
\hline
\end{tabular}

\begin{tabular}{|c|c|c|c|c|c|}
\hline \multirow{2}{*}{$\begin{array}{c}\text { Number of } \\
\text { floor } \\
\text { (Total building } \\
\text { height) }\end{array}$} & \multicolumn{5}{|c|}{ Performance (Target) Displacement (m) } \\
\cline { 2 - 6 } & \multicolumn{5}{|c|}{ ASCE 7-16 (Design Earthquake) } \\
\hline & A & B & C & D & E \\
\hline $3(10.5 \mathrm{~m})$ & 0.0591 & 0.0692 & 0.1034 & 0.1571 & 0.1872 \\
\hline $5(17.5 \mathrm{~m})$ & 0.1243 & 0.1387 & 0.1677 & 0.2429 & 0.3017 \\
\hline $7(24.5 \mathrm{~m})$ & 0.1871 & 0.2351 & 0.3243 & 0.3243 & 0.3835 \\
\hline $9(31.5 \mathrm{~m})$ & 0.3513 & 0.4009 & 0.4613 & 0.4761 & 0.5009 \\
\hline
\end{tabular}

In this study, a set of analyses were applied on reinforced concrete buildings for different story numbers and soil classes according to TBEC-2018 specially besides TEC-2007 and ASCE 7-16. The results of the applied study are expected to guide the designers through making choices about applying standards. The comparisons applied were done according to the natural seismic period, the relative story displacement and the base shear force. Turkish Seismic Standard especially the extensive TBEC-2018 was described as a step between ASCE 7-16 and TEC-2007. In addition, it was observed that despite considering the effective section rigidities both standards TBEC-2018 and ASCE 7-16 responded differently on the results. In this study, the dimensions of the columns and beams used into the reinforced concrete frame system weren't changed even for the situation of inadequacy so that the comparisons show only the differences between the standards. The results obtained from the study are as followed:

1. Using cracked section rigidities is desired by TBEC-2018 and ASCE 7-16. The ratios of the change in period according to the increase in the story numbers vary between 1.31-1.34 for TBEC/TEC and 1.27-1.49 for TBEC/ASCE.

2. While the period of TBEC-2018 was increasing with respect to TEC-2007 as a result of applying the moment of inertia of cracked section, no significant increase was obtained in the period of ASCE 7-16 although the effective section rigidities have already been applied for it. This is because of not applying Rayleigh calculations for the period calculations unlike the other two standards.

3. Applying the effective section rigidities for the new seismic standard and the American standard reduced the base shear forces. Yet, despite of this reduction, an increase in the shear forces of building elements like column and beam due to the effect of system over strength (in TBEC-2018 code " $D$ " and in ASCE7-16 code " $\Omega$ ") would be observed.

4. According to the base shear force, while the maximum value for buildings with less stories ( 3 and 5 ) and hard soils is given by TEC-2007, for buildings with more stories ( 7 and 9) and hard soils the maximum value is given by TBEC-2018 and for buildings with weak soils the maximum value is given by TEC-2007 again. In other words, 2018 standard increase the spectral acceleration values significantly for weak soils (especially C, D and E).

5. According to all of the three standards, the base shear force increases with the weaker soils in the buildings with 3,5 and 7 stories. Yet for building with 9 stories, the base shear force decreases after Z2 (ZC, C) soil classes for TBEC-2018 and increases in Z4 (ZE, E) soil classes for ASCE. 
6. It is obvious that even for the same seismic zone the behavior of the buildings is affected by the site class. The change in site class causes significant increases at the lateral displacement of the story. In a very recent study, similar results were reported by Azimi et al. (2019).

7. According to the residential buildings with 3 stories, while the higher results of the relative story displacement for the weakest soil are given by ASCE standard, for all other soil classes the higher results are given by TEC-2007 standard. In addition, according to the lateral rigidity, all the buildings are adequate in all soilclasses.

8. According to the values of the relative story displacement, the residential buildings in all soil classed can be arranged in terms of standards as TEC-2007>ASCE 7-16>TBEC-2018. Especially for Z3 (ZD, D) soil type, it was observed that the rigidity of the building is adequate for TEC-2007 standard and not adequate for ASCE and TBEC-2018 standards. In a similar way it was found that according to Z4 (ZE, E) soil classes, the rigidity of the building is adequate for TBEC-2018 and not adequate for TEC-2007 and ASCE standards Because of the less displacement of 2018 seismic standard with respect to 2007 seismic standard, it is concluded that more economical sections could be supplied by 2018 seismic standard.

9. According to the values of the relative story displacement, the standards for residential buildings with 7 stories in $Z 1$ $(Z A, A, Z B, B)$ and Z2 (ZC, C) soil classes are arranged as ASCE 7-16>TEC-2007>TBEC-2018. Yet in Z3 (ZD, D) and Z4 (ZE, E) soil classes, the standards are arranged as TEC-2007> ASCE 7-16>TBEC-2018. In a similar way it was found that according to $Z 3(Z D, D)$ soil classes, the lateral rigidity of the building is adequate for ASCE-2016 and not adequate for the other two standards. On the other hand, it was observed that the rigidity of the building in Z4 (ZE, E) soil classes is not adequate for any of the three standards.

10. Finally, according to the values of the relative story displacement, the standards for residential buildings with 9 stories in Z1 (ZA, ZB, A, B) and Z2 (ZC, C) soil classes are arranged as ASCE 7-16>TBEC-2018>TEC-2007. In the weaker soil classes, the standards are arranged as TEC-2007>ASCE 7-16>TBEC-2018. In a similar way it was found that according to the increase in story numbers and the application of weaker soil classes, the rigidity of the building is not adequate for any of the three standards. Yet it was found that according to hard soils, the rigidity of the building is adequate for TEC2007 standard and not adequate for the other two standards.

11. The smallest and the most unfavorable values of base shear force, displacement, relative story displacement, internal forces of the bearing elements and their distributions were obtained in Z4 (ZE, E) soil classes. Here according to all of the three standards and the buildings with different story numbers it was concluded that, the weaker the soil class is the larger the displacement values occur. This is why the soil class of the building has a significant effect on displacement and section responses. Hence the required analyses must be run according to a suitable soil class of the building. In this case it is obvious that the building would apply different displacements according to different soil classed.

12. It is possible to calculate different periods according to each of the three standards. Despite of the applications of uncracked section rigidity in TEC-2007 and cracked section rigidity in ASCE 7-16, the periods obtained by both of the standards were very close to each other. Yet in TBEC-2018 standard as a result of applying the cracked section rigidity higher values were obtained with respect to the other two standards. In fact, while the period calculations in both TBEC2018 and TEC-2007 standards are applied according to Rayleigh calculation, ASCE 7-16 applies the approximate method in which period calculations are applied according building height and structural system.

13. ASCE's demand displacement values are in any case lower than Turkish codes. TBEC-2018 reveals less displacement demands in high-rise buildings than TEC-2007. The closest results for the three regulations occurred on the softest grounds.

14. According to the results obtained from the static pushover analysis, a ductile behavior occurred in all of the structural systems and plastic hinge mechanism started from the beams firstly.

The comparisons in this paper were applied for buildings without irregularity or shear walls. As the obtained results would change according to the irregularities within the bearing system, it could be useful to apply the comparisons made for reinforced concrete frame buildings later for systems with shear walls and also for systems with shear wallframe. 
Earthquake codes have become much more comprehensive with the advancement of earthquake engineering science, the development of computational models and the increased possibilities of using computer package programs. Regional earthquake level differences, changes in construction technologies and economic conditions also caused the regulations to differ slightly from each other. In this study, calculation and control procedure differences among TEC2007, TBEC-2018 and ASCE 7-16 were evaluated. Although there is no significant difference in the calculation procedure, there are considerable changes in the earthquake forces with the changes in the ground properties and earthquake acceleration values. At the end of the study, it was observed that TBEC-2018 was based on more earthquake acceleration than ASCE depending on parameters such as number of floors and ground properties. Similar situation is valid in nonlinear analysis. ASCE's demand displacement values are in any case lower than Turkish codes. TBEC-2018 reveals less displacement demands in high-rise buildings than TEC-2007. The closest results for the three regulations occurred on the softest grounds.It is clear that different results can be achieved in the future studies by changing the type of structure, geometry and type of carrier system.

References

Abdel Raheem, S. E., Ahmed, M. M. M., \& Ahmed, M. M. e. a. (2018). Evaluation of plan configuration irregularity effects on seismic response demands of L-shaped MRF buildings. Bull Earthquake Eng, 16, 3845-3869. doi:https://doi.org/10.1007/s10518-018-0319-7

ACl 318-08. (1989). Building Code Requrements for Structural Concrete and Commentart. American Concrete Institute: ACl Committee 318. Retrived from https://www.concrete.org/store/productdetail.aspx?ltemID=318U19\&Language=English

AFAD. (2009). Disaster and Emergency Management Authority (AFAD). Retrieved from https://www.afad.gov.tr/en/2572/About-Us

AFAD. (2017). Disaster and Emergency Management Presidency (AFAD). Retrieved from https://en.afad.gov.tr/

Aksoylu, C., \& Arslan, M.H., (2019). Çerçeve+ Perde Türü Betonarme Binalarin Periyod Hesaplarinin TBDY-2019 Yönetmeliğine Göre Ampirik Olarak Değerlendirilmesi. Uludağ University Journal of the Faculty of Engineering, 24(3), 365-382. doi: https://doi.org/10.17482/uumfd.603437

Aksoylu, C., \& Arslan, M.H., (2019). Çerçeve Türü Betonarme Binaların Periyod Hesaplarının Farklı Ampirik Bağıntılara Göre İrdelenmesi. Bitlis Eren Üniversitesi Fen Bilimleri Dergisi, 8(2), 569-581. doi: https://doi.org/10.17798/bitlisfen.476312

Arslan, M. H. (2010). An evaluation of effective design parameters on earthquake performance of RC buildings using neural networks. Engineering Structures, 32(7), 1888-1898. doi:https://doi.org/10.1016/j.engstruct.2010.03.010

Arslan, M. H., \& Korkmaz, H. H. (2007). What is to be learned from damage and failure of reinforced concrete structures during recent earthquakes in Turkey? Engineering Failure Analysis, 14(1), 1-22. doi:https://doi.org/10.1016/j.engfailanal.2006.01.003

Azimi, P., Gazi, H., \& Alhan, C. (2019). Effects of Soil Amplification Factors on the Seismic Performance Potential and Cost of Reinforced Concrete Structural Systems. Teknik Dergi, 8803-8834. doi: https://doi.org/10.18400/tekderg.308431

ASCE7-10. (2010). Minimum Design Loads for Buildings and Other Structures. . Reston, VA: ASCE. Retrieved from https://www.waterboards.ca.gov/waterrights/water_issues/programs/bay_delta/california_waterfix/exhibits/docs/dd jardins/DDJ148\%20ASCE\%207-10.pdf

ASCE7-16. (2017). Minimum Design Loads and Associated Criteria for Buildings and Other Structures in Seismic Design Requirements for Building Structures: Structural Engineering Institute (pp. 89-121). Retrieved from https://ascelibrary.org/doi/book/10.1061/9780784414248

Demir, A., \& Kayhan, A. H. (2017). Comparison of the Time History Analysis Results Compatible With Turkish Earthquake Code 2007 and Turkish Building Earthquake Code 2016. Paper presented at the 4. Uluslararası Deprem Mühendisliği ve Sismoloji Konferansı, Anadolu Üniversitesi-Eskişehir.

Dogangun, A., \& Livaoglu, R. (2006). A comparative study of the design spectra defined by Eurocode 8, UBC, IBC and Turkish Earthquake Code on R/C sample buildings. Journal of Seismology, 10(3), 335-351. doi:https://doi.org/10.1007/s10950-006-9020-4

Erdem, M. M., \& Bikçe, M. (2017). Comparison of Maximum Reduced Relative Floor Drifts by Current (DBYBHY2007) and New Regulation Draft (TBDY2016). Çukurova Üniversitesi Mühendislik Mimarlık Fakültesi Dergisi, 32(2), 253-262.

Erdik, M. (2004). Report on 1999 Kocaeli and Düzce (Turkey) earthquakes. Retrieved from Cengelkoy, Istanbul: http://www.koeri.boun.edu.tr/depremmuh/eqspecials/kocaeli/Kocaelireport.pdf

ETABS.v17. CSI-Structural Software for Building Analysis and Design, ETABS v.17. Retrieved from https://www.csiamerica.com/products/etabs

Eurocode8. (2004). Design of structures for earthquake resistance Part 1: General rules, seismic actions and rules for buildings (European Standard EN 1998-1). Belgium. Retrieved from http://www.confinedmasonry.org/wp-content/uploads/2009/09/Eurocode-8-1-Earthquakes-general.pdf

Guerdouh, D., \& Khalfallah, S. (2019). Soil-structure interaction effects on the seismic performance of frame structures. Revista de la Construcción. Journal of Construction, 18(2), 349-363.

IBC. (2012). International Building Code International Code Council, Inc. (pp. 690). Country Club Hills, IL. Retrieved from https://roxana-il.org/wpcontent/uploads/2020/05/2012-IBC.pdf

Keskin, E., \& Bozdoğan, K. B. (2018). Evaluation of 2007 and 2018 Türkish Earthquake Code for the Province Of Kırklareli. Journal of Engineering and Science, $4(1)$. 
Kocer, M., Nakipoglu, N., Ozturk, B., Al-Hagri, M. G., \& Arslan, M. H. (2018). Comparison of TBSC 2018 and TSC 2007 Through The Values Of Seismic Load Related Spectral Acceleration Journal of Selcuk-Technic, 17(2), 43-58.

Leissa, A. W. (2005). The historical bases of the Rayleigh and Ritz methods. Journal of Sound and Vibration, 28(4), 961-978. doi: https://doi.org/10.1016/j.jsv.2004.12.021

NBCC-95. (1995). Canadian Commission on Building and Fire Code National Building Code of Canada. National Research Council of Canada, Ottawa, Ontario. Retrieved from https://nrc-publications.canada.ca/eng/view/object/?id=a6edb19d-6a71-44f7-84a9-bd9ed46a065d

Ozturk, M. (2018). An Evaluation About 2018 Turkey Building Earthquake Regulations and Turkey Earthquake Hazards Map Based On Central Anatolia Region. Journal of Selcuk-Technic, 17(2), 31-42.

Öztürk, H., Demir, A., Dok, G., \& Güç, H. (2017). Code Approaches on Effective Section Stiffness of Reinforced Concrete Columns. Paper presented at the 4. Uluslararası Deprem Mühendisliği ve Sismoloji Konferansı, Eskişehir.

Santos, C. H. S., Zanaica, L., Bucur, C., Lima, S. S., \& Arai, A. (2013). Comparative Study of Codes for Seismic Design of Strucutes. Mathematical Modelling in Civil Engineering, 9(1). doi: https://doi.org/10.2478/mmce-2013-0001

Sezen, H., \& Andrew, S. W. (2006). Seismic Performance of Industrial Facilities Affected by the 1999 Turkey Earthquake. Journal of Performance of Constructed Facilities, 20(1), 28-36. doi:https://doi.org/10.1061/(ASCE)0887-3828(2006)20:1(28)

Sezen, H., Whittaker, A. S., Elwood, K. J., \& Mosalam, K. M. (2003). Performance of reinforced concrete buildings during the August 17, 1999 Kocaeli, Turkey earthquake, and seismic design and construction practise in Turkey. Engineering Structures, 25(1), 103-114. doi:https://doi.org/10.1016/S0141-0296(02)00121-9

Sezer, R., Aksoylu, C., Kara, N. (2016). Investigation of Behavior of Structures According to Different Local Site Classes for L Type Reinforced Concrete Frame Building Having A1 and A3 Irregularities. The Online Journal of Science and Technology, 6(1), 21-32.

Sindel, Z., Akbaş, R., \& Tezcan., S. S. (1996). Drift Control and Damage in Tall Buildings. Eng. Struct, 18(12). doi: https://doi.org/10.1016/01410296(95)00215-4

TBEC. (2018). Turkish Seismic Earthquake Code (pp. 1-416). Retrieved from https://www.resmigazete.gov.tr/eskiler/2018/03/20180318M1-2-1.pdf

TEC. (2007). Turkish Earthquake Code (pp. 1-159). Retrieved from http://www.okangungor.com.tr/wp-content/uploads/2013/05/2007-TurkishEarthquake-Code.pdf

TS-498. (1997). Design loads for buildings: Turkish Standards Institute. Retrieved from https://abs.cu.edu.tr/Dokumanlar/2016/IMZ312/634693921_ts_498_yapi_elemanlarinin_boyutlandirilmasinda_alinacak_yuk.pdf

TS-500-2000. (2000). Turkish Building Code. Ankara. Retrieved from http://www.iibh.org/kijun/pdf/Turkey_06.pdf

Tunç, G., \& Tanfener, T. (2016). A comparison of 2007 and 2018 Turkey Earthquake Building Regulations with examples Paper presented at the 3rd National Structures Congress, Ankara.

UBC. (1997). Uniform building code. International Council of Building Ofcials: Whittier. Retrieved from http://docshare02.docshare.tips/files/21143/211437604.pdf

Vijay, N. K., Yogendra, S., \& Dominik H. L. (2012). A Comparative Study of Design Base Shear for RC Buildings in Selected Seismic Design Codes. Earthquake Spectra, 28(3), 1047-1070. doi:https://doi.org/10.1193/1.4000057

Wziatek, R. (2015). Comparative Design Of High Rise Rc Building According To Eurocode And ASCE 7-10/ACI318-11/IBC 2012. (Master Thesis), İstanbul Technical University, Institute of Science and Technology. Retrieved from https://polen.itu.edu.tr/handle/11527/13880. 